\title{
LA SEXUALIDAD EN EL PERÚ PRE-COLOMBINO: KAMASUTRA INDIANO
}

\section{SEXUALITY IN THE PRE-COLUMBIAN PERU: INDIAN KAMASUTRA}

Carlos Gamero Esparza: Universidad Inca Garcilaso de la Vega (Perú) carlos.gamero@ozu.es

\section{CURRÍCULUM VITAE}

Reconocido Periodista peruano del Diario OJO de Lima. Licenciado con Diploma de Honor en la Universidad Inca Garcilaso de la Vega.

\section{RESUMEN}

La sexualidad en el antiguo Perú fue una de las grandes manifestaciones culturales en sus viejos reinos y señoríos, donde cada cual tenía su manera particular de concebir la vida y sus creencias. Los hallazgos arqueológicos han permitido observar que existe una llamativa iconografía reproductiva. Podemos hablar de la existencia de un arte erótico en el Antiguo Perú. Pero el mundo de relaciones humanas que se creó difiere totalmente de los conceptos de sociedad que después fueron impuestos por los europeos que llegaron a estas tierras. Los alfareros moche fueron los grandes maestros de la cerámica preincaica y los autores del mejor arte erótico en el antiguo Perú. Existía incluso la promiscuidad sexual y se podían encontrar prostíbulos hasta en lugares donde era poco común ver un acto de sodomía. Q'enqo es un complejo de piedras conocido por ser uno de los lugares más sorprendentes del Perú Antiguo, no 
tanto por el simbolismo ritual que le dieron los incas, mitad culto al agua, mitad culto a la fertilidad, sino por la forma de su extraña construcción. Pero existe una ceguera e indiferencia académica importante sobre este tema que nos permitiría conocer el cómo éramos en otras épocas.

\section{PALABRAS CLAVE}

Arte erótico - Perú Antiguo - Sexualidad - Iconografía - Cultura

\section{ABSTRACT}

Sexuality in ancient Peru was one of the biggest cultural events in their old kingdoms and dominions, where each had its particular way of conceiving life and beliefs. Archaeological findings have allowed us to observe that there is a striking reproductive iconography. We can speak of the existence of an erotic art in ancient Peru. But the world of human relations, that was created entirely different from the concepts of society that were later imposed by the Europeans who came to this land. The Moche potters were masters of pre-Inca pottery and the authors of the best erotic art in ancient Peru. There was even sexual promiscuity and brothels could be found even in places where it was uncommon to see an act of sodomy. Q'enqo is a complex of stone known as one of the most amazing ancient Peru, not so much the ritual symbolism that gave the Incas worship half water, half fertility cult, but the shape of your strange construction. But there is a major academic blindness and indifference on this subject we would know how we were in the past.

\section{KEY WORDS}

Erotic Art - Ancient Peru - Sexuality - Iconography - Culture 


\section{ÍNDICE}

1. Introducción

2. El "arte erótico" no era ajeno al Antiguo Perú

2.1. Una insólita iconografía "reproductiva"

3. "...la primera representación erótica en el mundo..."

3.1. Antropomorfia de Eros al derecho y al revés

3.2. Los huacos retratos eran los libros del antiguo Perú

3.3. La "moda" mochica

3.4. Un Eros arácnido... y una teoría sobre el fin de los mochicas

4. La historia "inexistente"

4.1. Enfoque moderno de un viejo asunto

4.2. Condenando el pasado

4.3. Al encuentro del origen "perdido"

4.3.1. Consideraciones "non sanctas"

4.3.2. Kinsey: una vista de médico a la arqueología peruana

4.3.3. La humanidad de la arcilla I

4.3.4. La humanidad de la arcilla II

5. Templos de la fertilidad andina

5.1. "Inca Ullu": los falos del Collao

5.2. Q'enqo, otro adoratorio de la fecundidad

6. El servinacuy, matrimonio "de a mentiras"

7. Pampayrunas: prostitutas del incario

7.1. Sodomía ritual

8. ¿Quién les enseñó este arte a los aborígenes peruanos? (habla Kauffmann Doig)

9. Epílogo

9.1. Extirpadores de idolatrías y otros diablos... vade retro

10. ¿Sabía usted qué...?

11. Para saber más 
12. Notas

13. Fuentes

14. Origen de las imágenes

15. Recortes

15.1. Museo en Perú es ejemplo de que los primeros pobladores de nuestro continente sí sabían de erotismo.

\section{TEXTO:}

\section{Introducción}

El título de este reportaje no es otra cosa que el nombre de una de las obras de este acucioso investigador del comportamiento humano que es Artidoro Cáceres Velásquez (1) (Nota 1) Para él, el antiguo Perú es una verdadera caja de sorpresas y las sociedades que fundaron las viejas culturas andinas crearon un mundo de relaciones humanas que difiere totalmente de los conceptos de sociedad que después fueron impuestos por los europeos llegados a estas tierras. La sexualidad en el antiguo Perú fue una de las grandes manifestaciones culturales en sus viejos reinos y señoríos, donde cada cual tenía su manera particular de concebir la vida y sus creencias. Por ello queda justificado aquello de "Kamasutra indiano" como subtítulo de este trabajo. Descubramos, pues, lo desconocido e insólito de esta tierra maravillosa y única. Dejemos que ellas, las culturas del Perú antiguo, nos hablen desde el fondo del tiempo. Dejemos que ellos, los hombres y mujeres de ébano, hijos e hijas del Sol y del maíz, nos cuenten su historia de oro y terracota. 


\section{El "arte erótico" no era ajeno al Antiguo Perú}

"Agotados los conceptos de la Antropología, meditaciones de teólogos, argumentos e hipótesis de los psiquiatras, sociólogos y cuantos se han aventurado filosofar sobre sus funciones, el sexo, como la vida, continua siendo un misterio. Rafael Lacro Hoyle, en su libro CHECAN, revela este aspecto del Perú desconocido. Con un fondo eminentemente científico, presenta conclusiones resultantes de un estudio profundo de los ceramios eróticos."

"Las representaciones eróticas en el antiguo Perú alcanzan su esplendor (...) con la cultura Mochica, no sólo por el volumen sino sobre todo por la habilidad artística expresada en cada una de ellas. Con un profundo conocimiento de anatomía, el artista Mochica esculpe fragmentariamente el cuerpo humano y acabadas representaciones de los genitales, el acto sexual y el parto. En todas las piezas se muestra a la perfección el detalle: elaboradas con maestría no se limitan simplemente a reproducir, son verdaderos retratos psicológicos."

Introducción al "Mundo Mochica" - "Museo Arqueológico Larco". (24)

\subsection{Una insólita iconografía "reproductiva"}

El antiguo peruano fue hombre eminentemente religioso, temeroso de las fuerzas de la naturaleza, adorador de los astros, supersticioso y fetichista, y además un gran creativo como pocos. En pocos países del mundo se pueden encontrar unas manifestaciones culturales tan impregnadas de humanidad, con su cuota de mito, magia y rito, sin desprenderse de la tierra donde se nace, se vive y se muere, la vieja

"Mamapacha" (Nota 2) que les prodigaba el alimento y el abrigo. Eran pueblos que prosperaban siempre alrededor de un valle o a orillas del mar, a veces ingeniándoselas de forma admirable para vencer la adversidad de un medio hostil; 
fueron personas que se instalaron en estas regiones atraídas por la necesidad de encontrar el sustento; fueron pueblos dedicados a la agricultura, la domesticación de animales y el comercio, incluso eran pescadores y navegantes, y lograron desarrollar sociedades urbanas y teocráticas muy complejas que, además, ejercían una influencia militar y política sobre sus vecinos más débiles, a quienes sojuzgaban y reducían a la servidumbre... hasta que el pueblo sometido se le rebelaba o eran conquistados por otro más poderoso.

Por este motivo en el Perú es frecuente escuchar a los historiadores y arqueólogos hablar de lapsos de tiempo o "periodos" para señalar las épocas en que surgieron estos pueblos, se desarrollaron, alcanzaron su apogeo, entraron en decadencia, y finalmente desaparecieron; así se dice, por ejemplo, que hubo un horizonte "Formativo" o "Temprano", que es el más antiguo, luego un periodo "Intermedio" y, finalmente, otro "Tardío" (Ver cuadro de la figura 1a más abajo). De esta forma tenemos una cronología entendible para una historia supuestamente sin escritura (Nota 3). 


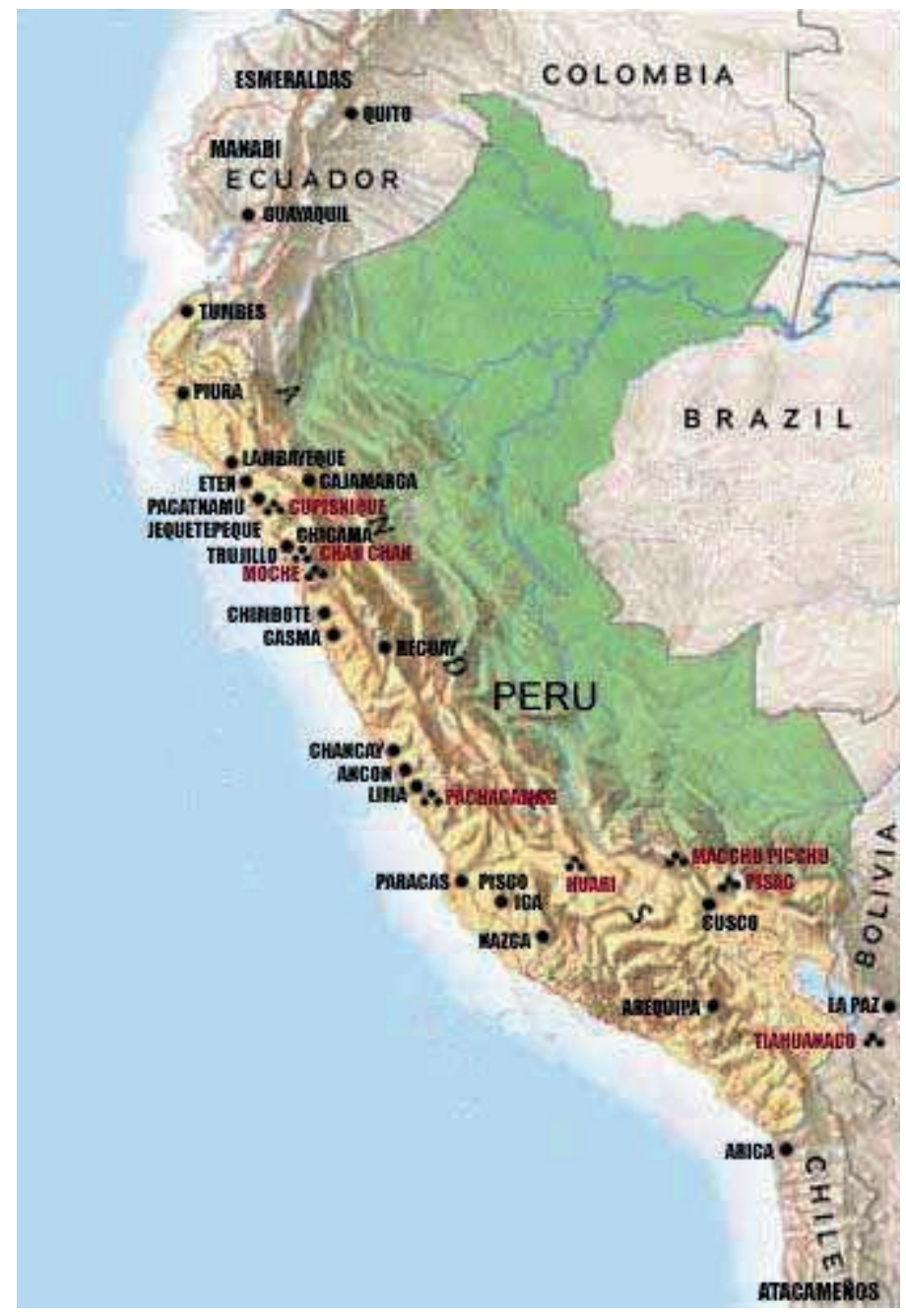

Figura 1b. Distribución geográfica de las culturas precolombinas en el Perú.

Ilustración del portal "Culturas del Perú Precolombino".

La historia del antiguo Perú es como un enorme rompecabezas cuyas piezas son los hallazgos arqueológicos y el estudio e interpretación de los testimonios dejados por estos pueblos. Un trozo de tela, un hueso de animal convertido en instrumento musical, una piedra tallada o un dibujo rupestre pueden decirnos muchas cosas. Por fortuna las condiciones medioambientales -como la sequedad del clima en la zona andina o la aridez en los desiertos costeros - han permitido la preservación de muchos restos humanos sepultados en tumbas donde los yertos despojos realizan su viaje al mas allá rodeados de todo aquello que amaron en vida: el ajuar funerario donde, a la manera del antiguo Egipto, no podía faltar ni la chicha de jora -bebida fermentada hecha a base de maíz - ni sus prendas favoritas. 
Es en este contexto que los restos materiales de las viejas culturas son prácticamente la única forma de saber cómo eran los antiguos creadores de estas civilizaciones andinas peruanas, y entre estos, las manifestaciones artísticas plasmadas en la piedra, la arcilla y cualquier materia prima susceptible de ser tallada, moldeada, esculpida, forjada, o bien teñida, pintada o dibujada. Y la cerámica fue, entonces, una de las modalidades de expresión artística más recurridas, y con ella nos dejaron una historia viva.

En el "Museo Brüning" (2) de Lambayeque (ciudad de la región Lambayeque, muy cerca de Chiclayo, en el norte del Perú) se conserva una curiosa estatuilla de oro atribuida a la cultura Vicús (3) con indudables rasgos femeninos: la "Venus de Frías". Esta figura, como otras, es hueca, lo que ha hecho suponer a los arqueólogos que debió tratarse de objetos de culto. En el caso de la famosa "Venus", se piensa que pudo estar dedicada a un culto a la fertilidad o feminidad, algo que parece repetirse en diversas manifestaciones culturales a lo largo de la geografía peruana precolombina

\section{$\underline{\text { Una "Venus" peruana }}$}

Llamada también la Venus de Frías, representa a una mujer desnuda trabajada en oro repujado, martillado y soldado por mitades. Se advierte cierto movimiento para la cabeza y para las manos. Parece que las manos descansaban en algún objeto en cuyo caso la estatuilla formaba parte de un conjunto. Los rasgos de la estatuilla son notoriamente femeninos a pesar de sus anchos hombros y angostas caderas. Dos argollas penden de las orejas y los ojos son enormes. 


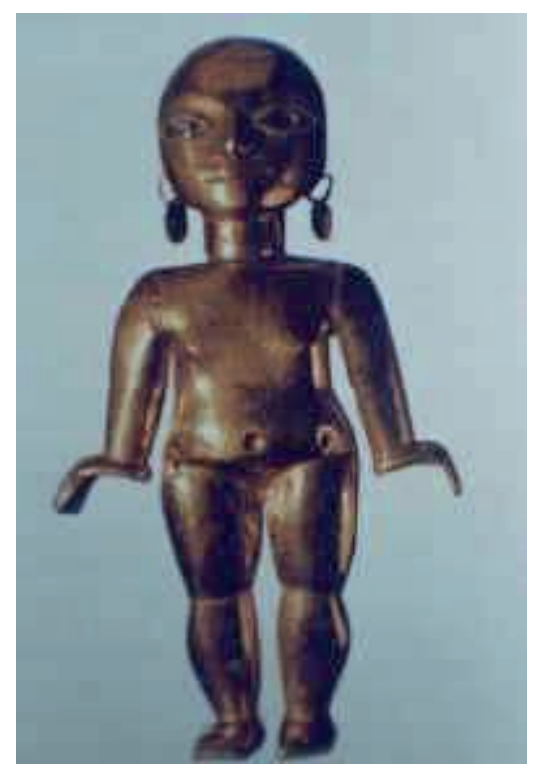

Figura 2. La figura de Frías

Estatuillas parecidas se han encontrado en Quimbaya (Colombia),1 o cual viene a confirmar una influencia cultural llegada del norte, que también se hace presente en la forma de las tumbas.

Para el arqueólogo Lumbreras, la estatuilla de Frías es importada. En el "Arte y la Vida Vicús" dice: "sin lugar a duda fue hecha en Esmeraldas (Ecuador) o en Tumaco (Colombia) pues pertenece al estilo Tolita precisamente de la época de los Desarrollos Regionales" .El arqueólogo Kauffmann Doig, la da como "perteneciente al círculo Vicús", y sólo semejante a las de Colombia. (El Perú Antiguo).

Pese a estos criterios de que la estatuilla es importada y no una manifestación del arte piurano antiguo, se la ha declarado Patrimonio Prehispánico Cultural del Departamento de Piura con la Resolución Directoral 005-82DRP del Instituto Nacional de Cultura, Filial Piura.

La figurilla ha estado durante mucho tiempo en el "Museo Brünning" de Lambayeque. El 20 de Noviembre de 1956, el conservador del Museo, don Oscar 
Fernández de Córdova, la decomisó de unos huaqueros que la ofrecían en venta y la llevó al Museo.

La estatuilla que es toda de oro, pesa 60 gramos y mide $153 \mathrm{~mm}$ de alto. Se construyó con oro laminado de 22 quilates. El Director del Museo Walter Alva -descubridor de la tumba del Señor de Sipán- la consideraba perteneciente al estilo de Frías

El antropólogo Luis Chaparro Frías, Director del Patrimonio Cultural de Piura, con admirable constancia, por muchos años estuvo reclamando para Piura, la estatuilla.

En 1999, aprovechando que el Ministerio de Educación era ocupado por el sullanero Felipe García Escudero, redobló las gestiones y al fin obtuvo que el 30 de Septiembre de ese año, la valiosa obra retornase a Piura con otras 61 piezas arqueológicas. Como era de suponer, el arribo de la figurilla, dio origen a un acto de gran solemnidad en él que estuvo presente el Ministro de Educación.

Nota: El texto de este recuadro y la ilustración han sido extraídos del sitio Web del investigador peruano Reynaldo Moya (4).

Más abajo de Lambayeque, a unos 200 kilómetros al sur de la ciudad de Lima, se encuentra la península de Paracas (Ica) (5). Aquí, entre las arenas del desierto, en los años 20, el arqueólogo Julio C. Tello, considerado el padre de la arqueología peruana (6), hizo un sensacional descubrimiento: miles y miles de fardos funerarios sepultados en verdaderas ciudades de los muertos, a las que bautizó como "Paracas Necrópolis" y "Paracas Cavernas" (5). En una de estas tumbas colectivas, que el Carbono 14 fechó en 300 a. de C., es decir, casi contemporáneos a los mochica y antecesores de los nasca, Tello encontró una momia que estaba envuelta por un curioso manto policromo que ha sido identificado por Artidoro Cáceres como una muestra de arte erótico en esta árida región. 
"...existe una simbología sumamente importante -explica Cáceres - representando la maternidad, la herencia, la concepción; según creen algunos investigadores peruanos. En la parte inferior (del manto policromo) una cabeza de niño, encima una de adulto. A un lado y hacia arriba, una serie de cabezas menores que van completándose y perfeccionándose hacia abajo y que proceden desde arriba, de otra cabeza adulta y celeste. Al lado y paralelamente, otra hilera que comienza en otra cabeza de tinte rojo y que se continúa hacia abajo con cuatro figuras redondeadas. Éstos podrían ser óvulos, los anteriores espermatozoides. Más hacía afuera, otra figura que representa a un animal (¿filogenia?) y, a la periferia, 3 elementos en forma de pera o coniformes (¿espermatozoides?) ¿Qué representa realmente esta figura? -Se pregunta este autor - En la probabilidad interpretativa hay lugar a la fantasía." (1)

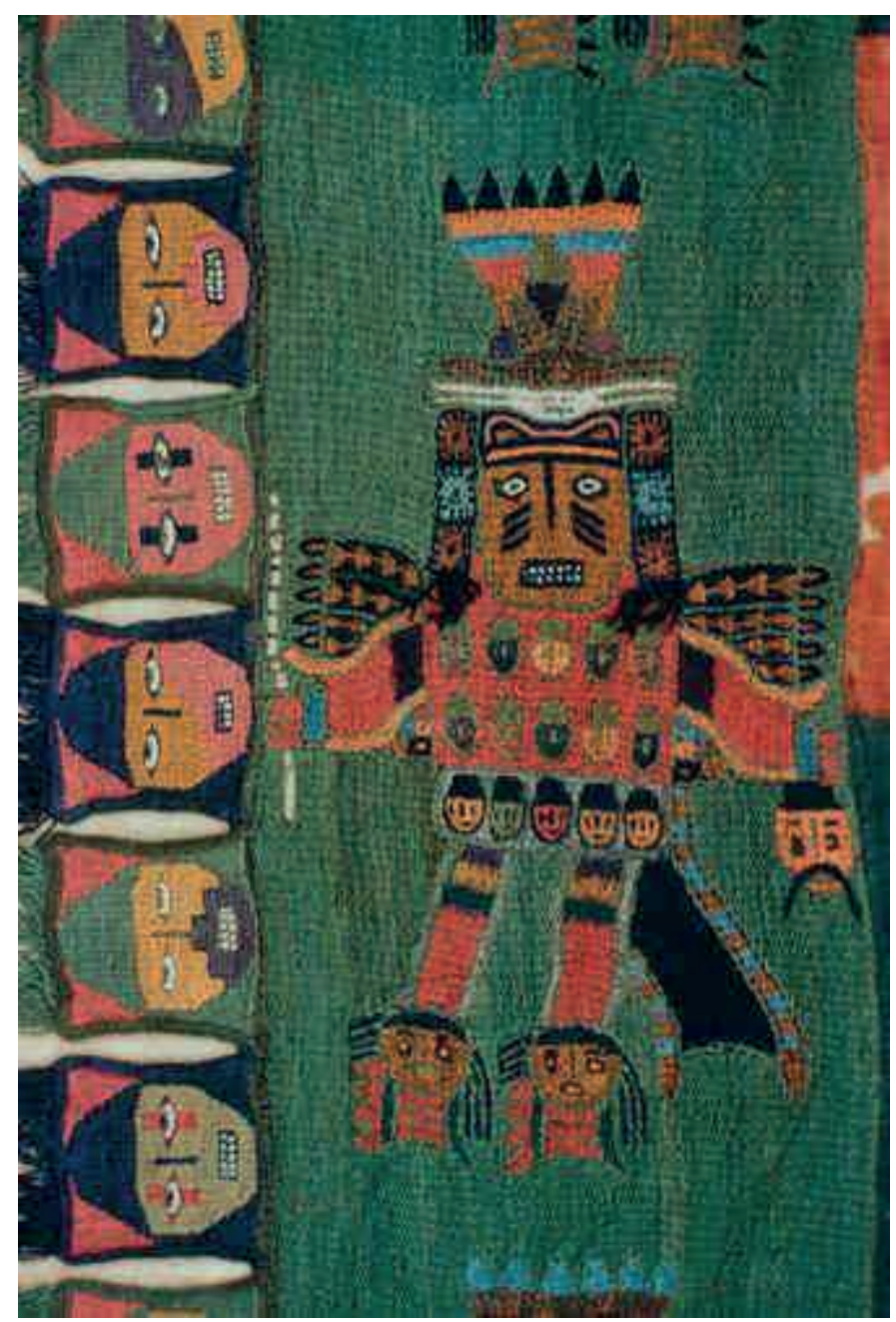

Figura 3. Un manto de Paracas similar a éste llamó la atención del doctor Artidoro Cáceres. La figura, de vivísimos colores, tejida con una técnica depurada, se ha mantenido inalterable al paso del tiempo. El "desfile de cabezas" y el personaje que adornan esta imagen resultan por cierto evocadores. Espécimen 382-10 (detalle), "Museo Nacional de Arqueología, Antropología e Historia del Perú" de Pueblo Libre (Lima). Foto de Anne Paul. 
Regresando de nuevo al norte peruano, pero esta vez a la zona andina central, entre el Callejón de Huaylas y la provincia de Huari (Ancash), nos topamos con los vestigios de un pueblo que, alrededor del segundo milenio A. C., extendió sus dominios desde el Pacífico a la región amazónica, ocupando buena parte del actual territorio peruano. Aquí es frecuente encontrar esculturas monolíticas pétreas de la civilización de Chavín (7), considerada una de las más viejas de América. Se trata de estatuas de rasgos masculinos. Hay estudiosos que ven en ellas falos (Nota 4) que apuntan al cielo (casualmente el mismo tipo de esculturas fálicas que también se encuentran esparcidos por la región del lago Titicaca, en Puno, cerca la frontera con Bolivia, atribuidas a la cultura Tiahuanaco. (8) (Ver en el capítulo: 4. Templos de la fertilidad andina, el subcapítulo 4.1. "Inca Ullu": los falos del Collao.)

También hay figuras líticas talladas de Chavín y de Recuay -cultura que siguió a Chavín - que muestran órganos femeninos... ¿otra vez un culto a la fertilidad... o a la feminidad? El hecho de que esta iconografía "reproductiva", como las ya vistas, de índole masculina, se repita trascendiendo el tiempo y el espacio en todo el antiguo Perú hace presumir al doctor Cáceres que tales esculturas pudieron haber tenido alguna finalidad ritual relacionada con la fertilidad, dado que siempre se las ubica en lugares prominentes, como en la cima de un cerro, por ejemplo. (Nota 4) 


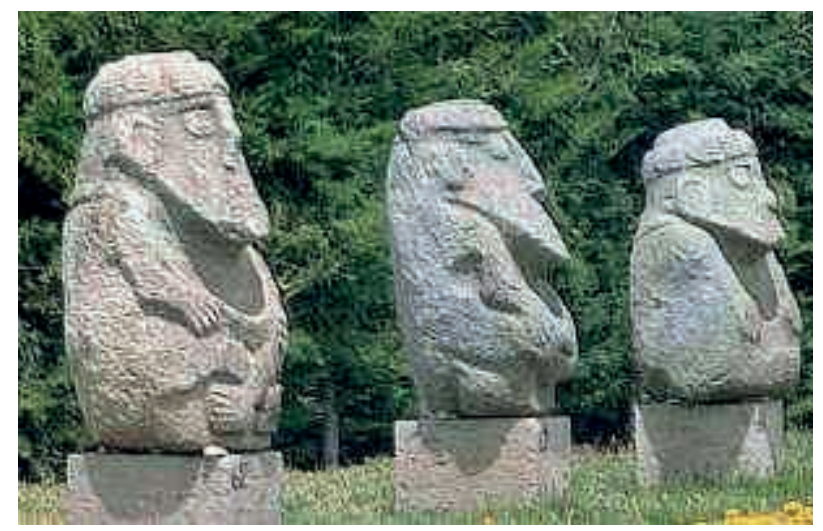

Figura 4a. Estas estatuas pétreas procedentes de la zona de Recuay, al sur de la ciudad de Huaraz, capital de la Región Ancash (Andes centrales peruanos), se conservan en el "Museo Regional" de esta ciudad. Hay estudiosos que creen ver en la peculiar forma de estas esculturas ciertas reminiscencias fálicas. Fotografía obtenida del portal turístico de la ciudad de Huaraz.

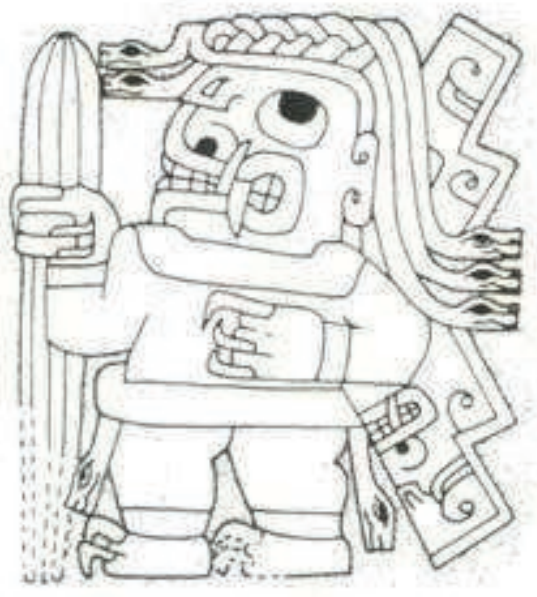

Figura 4b. ¿Una vinculación de "deidades" antropomorfas con atributos sexuales masculinos? Lo cierto es que este extraño ser cuya figura forma parte de la iconografía que adorna la "plaza en U" del llamado "Santuario de Chavín" atrae la curiosidad de los estudiosos. Obsérvese las "sierpes" que asoman bajo el faldellín de este personaje lítico. Más de uno ha creído ver en estos animales los atributos masculinos que todos conocen. Ilustración del sitio Web "Culturas Preincaicas" del portal "Morrion.com".

\section{3. "...la primera representación erótica en el mundo..."}

"... a ellos les gustaba representar todo: enfermedades, batallas, frutos; hubiera sido sospechoso que no tengan nada sobre sexo. Pero, si hacemos una estadística, el porcentaje dedicado a ello es mínimo. Incluso los ceramistas Moche tuvieron limitaciones." 
Federico Kauffmann Doig. (23)

"Se hace difícil concluir que tal cerámica fuera simple pornografía -escribe Nigel Davis - . Por otra parte, si estas escenas son consideradas en un contexto religioso o ceremonial, estarían lógicamente relacionadas con la noción de fertilidad, pero si fuera este el caso, ¿por qué tantas vasijas representan el coito anal?"

Amelia Die (39)

\subsection{Antropomorfia de Eros al derecho y al revés}

Entre las manifestaciones plásticas de la cerámica precolombina peruana, el arte erótico fue uno de los que alcanzó el mayor desarrollo. Los diestros artesanos demostraron aquí una técnica y un dominio de las formas, tamaños, perspectivas, que daba vida y color a sus creaciones; y les transmitían esa "alma" que daba emoción, sensibilidad, sensualidad, realismo y movimiento a las figuras que salían de sus manos, constituyendo esto una verdadera antología de la psique humana. En estos huacos, los hombres y las mujeres del antiguo Perú, y aún los animales, son seres vivos... o muertos que no parecen estarlo (es que nunca se ha visto a muertos más vivos que éstos...); que llegan de la noche de los tiempos, y parecen hablar, llorar, reír o gritar.

La terracota, el barro, la arcilla, la piedra, la madera... todas las materias primas que proporcionaba la naturaleza le sirvieron al peruano de las épocas preinca e inca para reflejar su vida diaria. Pero fue la cerámica, por estar fabricada con materiales muy fáciles de conseguir, pues estaban allí nomás, en la tierra, en las montañas, en las riberas de ríos y lagos, en las orillas del mar, la modalidad más socorrida. Con ella fueron confeccionadas las primorosas obras de arte que ahora adornan los mejores museos de arte antiguo y arqueología del mundo. 
Varias culturas preincaicas hicieron de la arcilla y el barro el mejor escaparate de su cotidianeidad, y en éstas el arte erótico no fue la excepción. Este tipo de expresiones artísticas, al decir de los investigadores, florecieron principalmente en la llamada "época de auge" o "clásica" - entre el primer milenio A. de C. y el siglo IX de nuestra Era, aproximadamente-, y no tuvieron parangón dentro del contexto de las creaciones artísticas en el mundo antiguo fuera de América. Para el notable investigador del comportamiento humano, Alfred Kinsey, (9), "Los vasos eróticos peruanos son la primera representación erótica en el mundo". Ninguna civilización de la tierra ha sabido plasmar en la arcilla tal riqueza plástica en tanta variedad... iy en tal variedad!... y esto es una constante en todo el Perú antiguo; y encontramos escenas de acendrado erotismo, y también de las otras, poco "amorosas", del llamado "sexo invertido", que nos dicen que tanto en el antiguo Perú, como en Europa -de otro modo habría que preguntárselo a los romanos - o en Asia -si no, que lo digan los persas o los asirios - , también se cocieron habas... o pallares, y no sólo entre los moches...

Y los ejemplos los hemos escogido al azar: en un ceramio Nasca (Ica) (10) se ve una cabeza con dos rostros. Uno tiene la boca abierta y el otro, como si estuviera chupando algo, tiene los labios como si silbara. ¿Se trataba acaso de un bisexual?, no lo sabemos, pero lo cierto es que ver esta imagen da lugar a muchas conjeturas; en un huaco retrato moche se ve a un hombre que muestra un enorme pene; cerca de allí, en otro huaco, de Virú (sur de Trujillo), una figura femenina muestra sus órganos genitales, mientras que en un tercer ceramio, esta vez moche, un hombre y una mujer se hacen caricias.

En otra vasija, de Chimú (la Libertad) (12), una mujer nos muestra su prominente vientre, mientras se agarra la barriga con gesto dolorido. Para los arqueólogos no hay ninguna duda -si no que se lo digan sus mamás - ... ¡válgame Dios, viene un bebé! En otro vaso, también Chimú (aproximadamente 1000 después de C.), se observa a 
dos hombres acariciándose (¿homosexualidad preincaica?). En otra pieza de esta misma cultura, otro hombre, de gesto implorante, muestra su lánguido pene convertido en serpiente enroscada (¿impotencia? ¿enfermedad?).

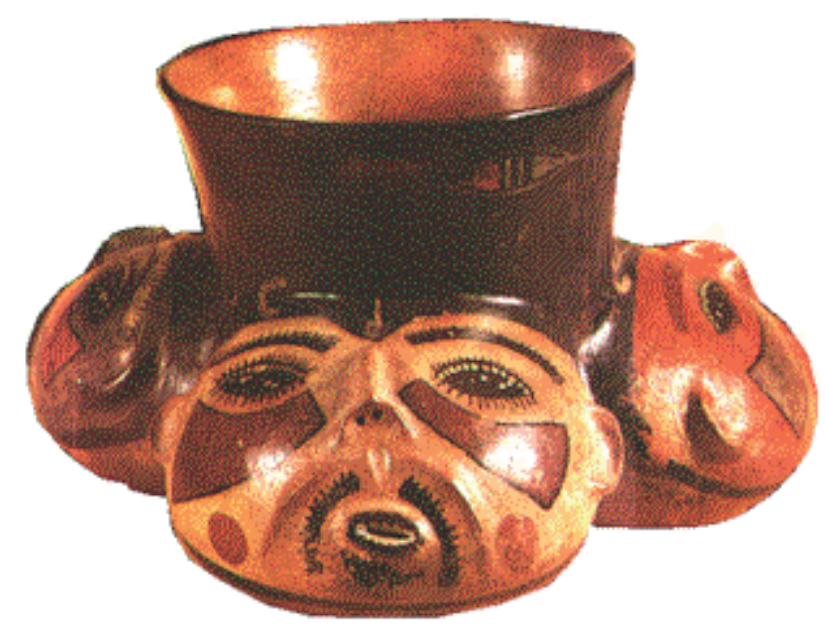

Figura 5. Dicen que ésta es una de las típicas cabezas-trofeo de Nasca, pero no es así. Muy al contrario, el individuo representado en este ceramio tiene los ojos bien abiertos y parece silbar o enviar un beso volado. Se trata de una cabeza con dos rostros, cada cual con una expresión bucal diferente. Algunos autores creen ver en éste huaco algún tipo de desviación sexual (¿bisexual). Ilustración del portal "Morrion.com".

\subsection{Los huacos retratos eran los libros del antiguo Perú}

Pero fueron los anónimos alfareros moche, sin duda, los grandes maestros de la cerámica preincaica y los autores del mejor arte erótico en el antiguo Perú. Ellos, mejor que nadie, plasmaron con la arcilla y el barro sus costumbres sexuales hasta los límites de lo inimaginable. El arte mochica configura no sólo la representación realista y tridimensional de la vida cotidiana, sino también la vivida secuencia de emociones del pueblo moche. Se han encontrado hermosas obras artísticas que retratan hasta el mínimo detalle todos los aspectos de su vida y costumbres, incluyendo la sexualidad.

Gracias a estos ceramios, también conocidos como "huacos" -sin duda la mejor fuente de información para los arqueólogos a falta de escritura - (Nota 5), se sabe cómo y 
qué comían, cómo bailaban, qué enfermedades padecían -la uta, por ejemplo, es representada de forma desgarradora: los enfermos presentan las carnes que parecen colgajos sobre la piel, dejando lugar a los huesos -; cómo eran sus dioses, cómo se ejercía la justicia -se ve a ladrones a quienes se les ha amputado una mano o se les ha mutilado un ojo al más puro estilo de Hammurabi-; o cómo realizaban sus sangrientos rituales -los prisioneros, por ejemplo, eran sacrificados a los dioses destrozándoles la cabeza con unos mazos - ; o cómo se hacían la guerra... y el amor los "huacos" retratan hasta las emociones y los sentimientos de los personajes, tales como el odio, el dolor, el placer, el afecto, la angustia, la alegría, la tristeza, la satisfacción, la ternura, la brutalidad...-, y hasta se sabe qué desviaciones sexuales practicaban y cuáles fueron las males de transmisión sexual padecidos por estas gentes. (Nota 6)

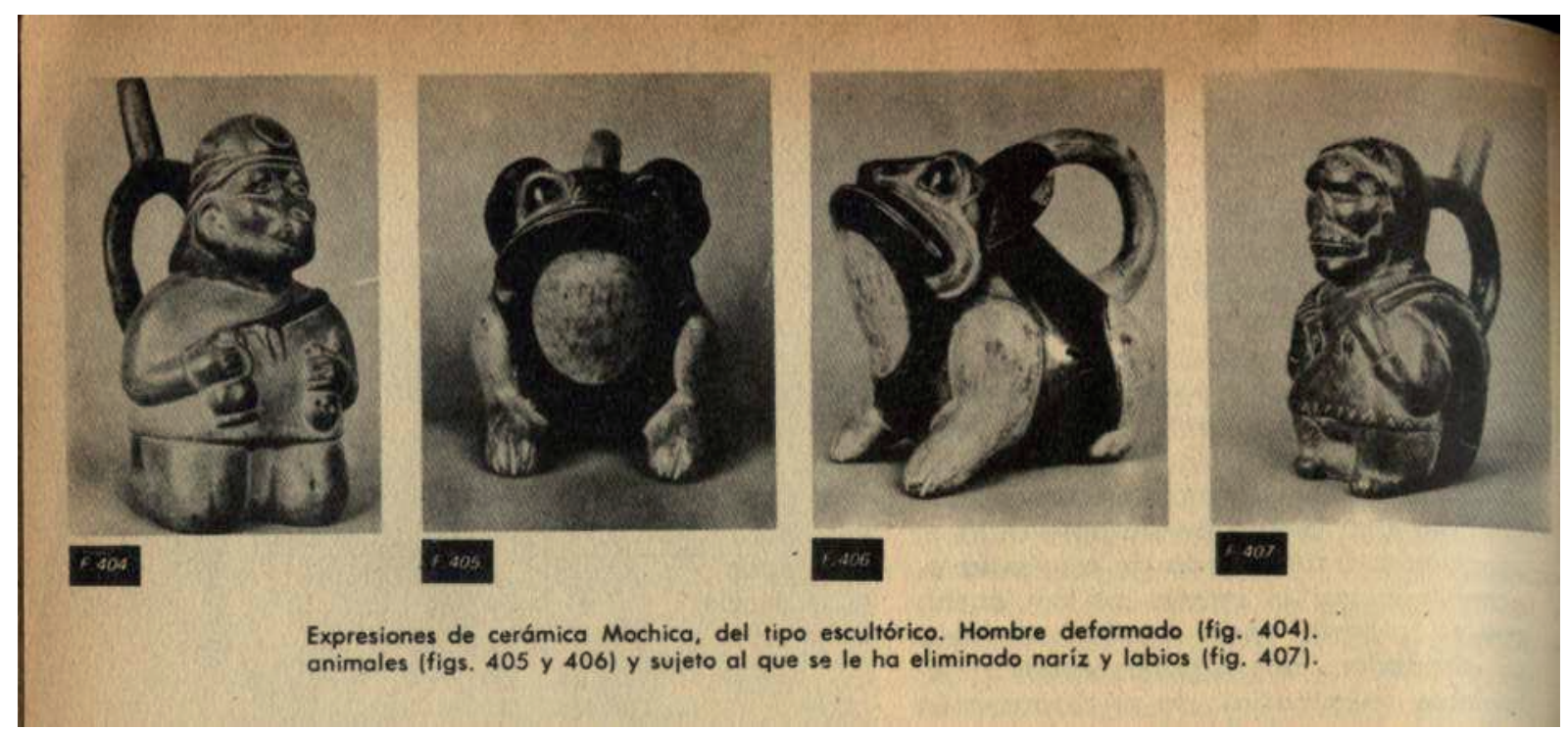

Figura 6a. Secuencia de huacos-retratos extraídas del libro "Arqueología Peruana" citado en este trabajo. Tal como dice la leyenda de los mismos, mostrados de izquierda a derecha, se trata de "Expresiones de cerámica Mochica, del tipo escultórico. Hombre deformado (izquierda). Criminales (figuras centrales) y sujeto al que se le han eliminado nariz y labios (derecha)" (22). 


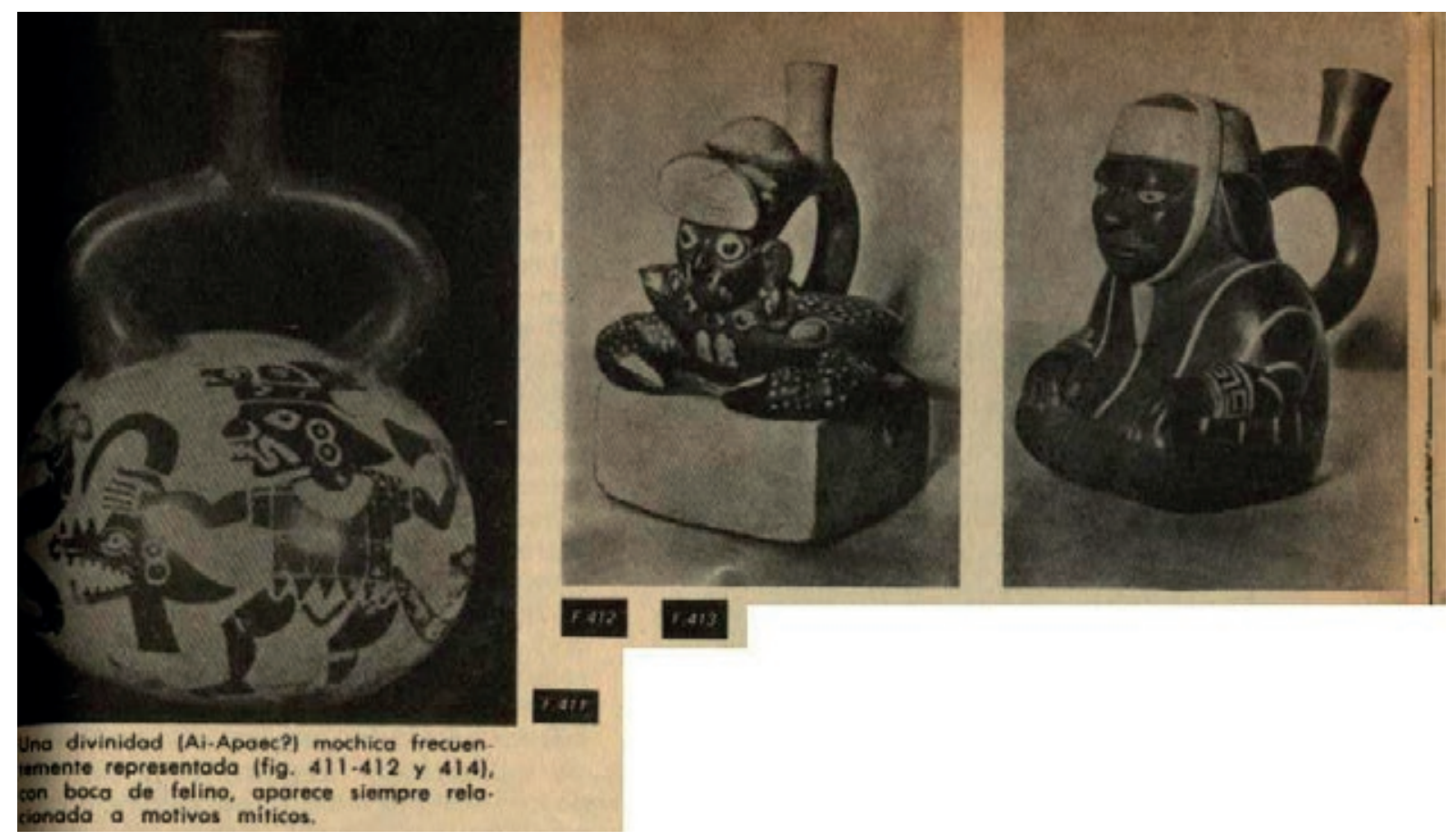

Figura 6b. En esta segunda secuencia, procedente de la misma obra de Kauffmann Doig, podemos apreciar tres figuras míticas... "Una divinidad (Ai-Apaec) Mochica frecuentemente representada. Con boca de felino, aparece siempre relacionada con motivos místicos". (22) 


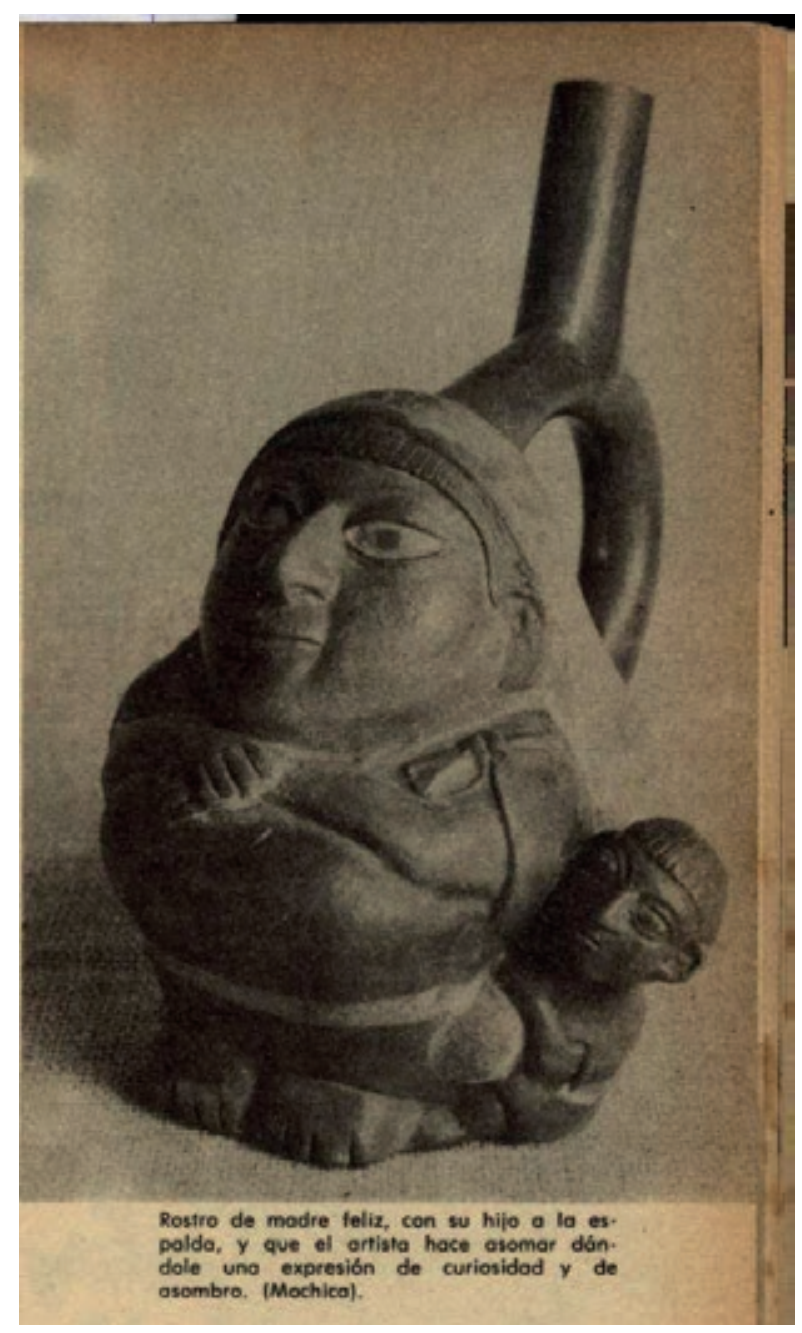

Figura 6c. En este ceramio Mochica, una orgullosa madre retratada con su hijo... "Rostro de madre feliz, con su hijo a la espalda, y que el artista hace asomar dándole una expresión de curiosidad y de asombro". Leyenda de la figura 415 de la obra de Kauffmann Doig. (22) 


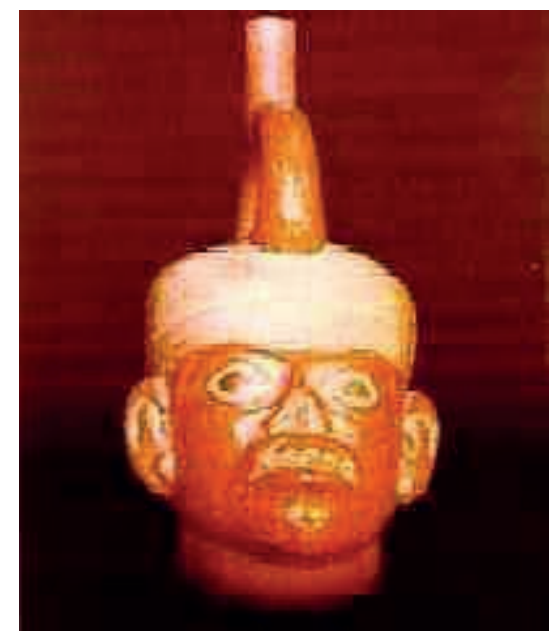

Figura 6d. Este huaco-retrato, que nos muestra los estragos de la uta en el rostro de un hombre mochica, se ha convertido en el emblema de la Sociedad Peruana de Dermatología. Esta enfermedad que destruye la piel y los tejidos, era y es muy común en el norte del Perú. Ilustración extraída del portal de la SPD.

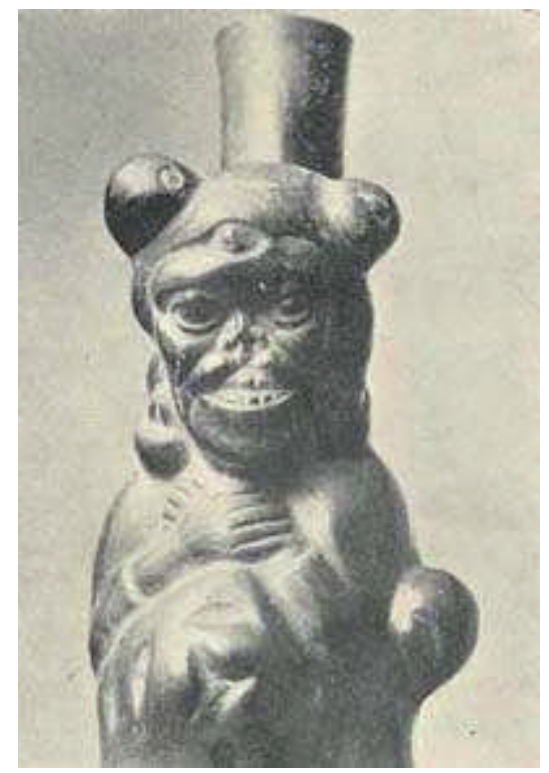

Figura 6e. "Huaco antropomorfo que representa un enfermo con tumores y mutilaciones". Este ceramio, descubierto en el valle de Chicama (La Libertad, Perú) a principios del siglo XX, le sirvió a Julio C. Tello para ilustrar una de sus tesis de doctorado. Ilustración de "La antigüedad de la sífilis en el Perú". Biblioteca de la Universidad Nacional Mayor de San Marcos.

Hay una gran cantidad de ceramios mochica que representan, por ejemplo, la actitud impasible y serena de los hombres ante un parto, o representaciones de mujeres junto a cadáveres femeninos. Lo curioso es que se han encontrado muy pocas muestras de homosexualidad, cuya presencia, rara en el arte erótico, es innegable en el antiguo Perú -incluso los cronistas de los primeros años de la Conquista hablan de esta práctica entre los "yndios" del mismo sexo-. Por su parte, del lesbianismo se ha encontrado muy pocos rastros, salvo en uno que otro huaco mochica. Muy raras son también las recreaciones de uniones carnales entre seres humanos y animales; sin 
embargo, abundan las escenas coitales entre animales de diversas especies, como perros, gatos, cuyes, llamas, etc, etc...

La mayoría de las piezas de alfarería descubiertas "in situ" formaban parte de ofrendas depositadas en las tumbas para acompañar a los muertos en su viaje al más allá. Como ya indicamos, acompañando a estos ceramios se depositaba desde la ropa del difunto hasta sus armas, la comida y su infaltable chicha de jora...; todo aquello que poseía o le gustaba en vida al difunto, se lo llevaba a la tumba. Se puede decir que estas piezas de alfarería, que iban desde platos y envases hasta los inconfundibles jarros de asa puente, de uno o dos picos, en forma de jarro o vaso, eran -hasta que no se encuentre otra cosa - los verdaderos libros de historia del Perú precolombino, pues en ellos se retrata la vida y las costumbres de estas gentes. Todo estaba allí, para la interpretación arqueológica, la mejor manera de conocer el pasado a falta de testimonios escritos.

\subsection{La "moda" mochica}

Se sabe que antes y poco después del inicio de la Cultura Moche, otros pueblos ya fabricaban huacos eróticos. Los más antiguos vasos con este tipo de arte fueron los pertenecientes a las culturas Vicús, Virú y Salinar, datados entre los años 500 a. de C. y 200 de neustra Era. Pero este arte tuvo que esperar para alcanzar su época dorada, durante el periodo Moche, alrededor del 500 d. C. Se conoce que, durante mucho tiempo, la cerámica erótica fue más abundante en la costa norte que en el resto del país. Dentro del marco de las civilizaciones del Perú preincaico, la nación moche fue la que más influyó en la vida social, política, económica y religiosa del norte peruano y aún del sur del Ecuador. Todos los pueblos que habitaron el Perú septentrional durante los siete siglos que duró la hegemonía de este estado teocrático y militar, tuvieron que vivir sometidos al "modus vivendi" impuesto por los mochica, un 
"modus vivendi" que incluso se reflejó en la actividad comercial, y que llegó, según algunos autores, hasta Centroamérica.

No es de extrañar, entonces, que las manifestaciones artísticas de pueblos tan ajenas como Vicús o Virú vivieran una especie de "moda" mochica que se manifestó también en el arte erótico -por tal motivo no es casual encontrar ceramios, por ejemplo, de Vicús (considerados los maestros de los moches, que también fueron sus contemporáneos por un tiempo), con características mixtas, las propias y las ajenas... de la tierra del Señor de Sipan, es decir, los alumnos se convirtieron a la vez... en los maestros - .

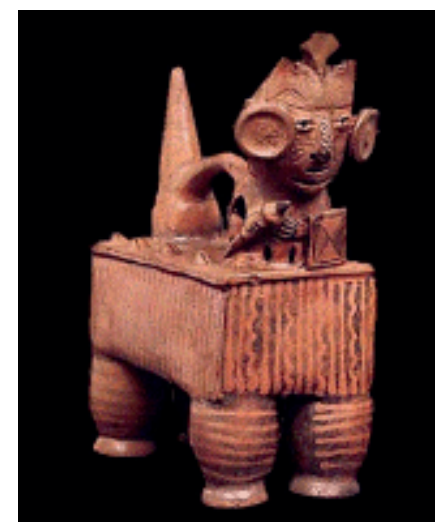

Figura 7a. La cultura Virú se desarrolló en un pequeño valle ubicado al sur de la ciudad de Trujillo (Perú) y fue contemporánea de Vicús. Este pueblo, también llamado "Gallinazo", nos dejó una cerámica en color negativo cuya técnica precedió a la de los mochicas, como deja entrever este curioso huaco. Ilustración del portal "Arqueología de Perú.com".

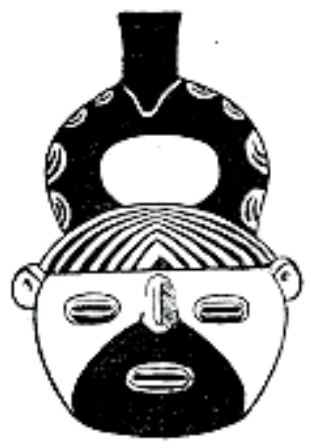

Figura 7b. "Vasija de tipo llamada "de estribo", decorada a dos colores, rojo y blanco. Ojos, boca, nariz y orejas en relieve. Estos recipientes en forma de cabeza humana más primitivos son poco frecuentes $y$ constituyen un precedente directo de las cabezas-retratos de la cultura de Moche. hallada en Salinar, Valle de Chicama. Según Larco Hoyle". Ilustración del portal "Culturas del Perú precolombino - Recuay, Salinar y Gallinazo". 


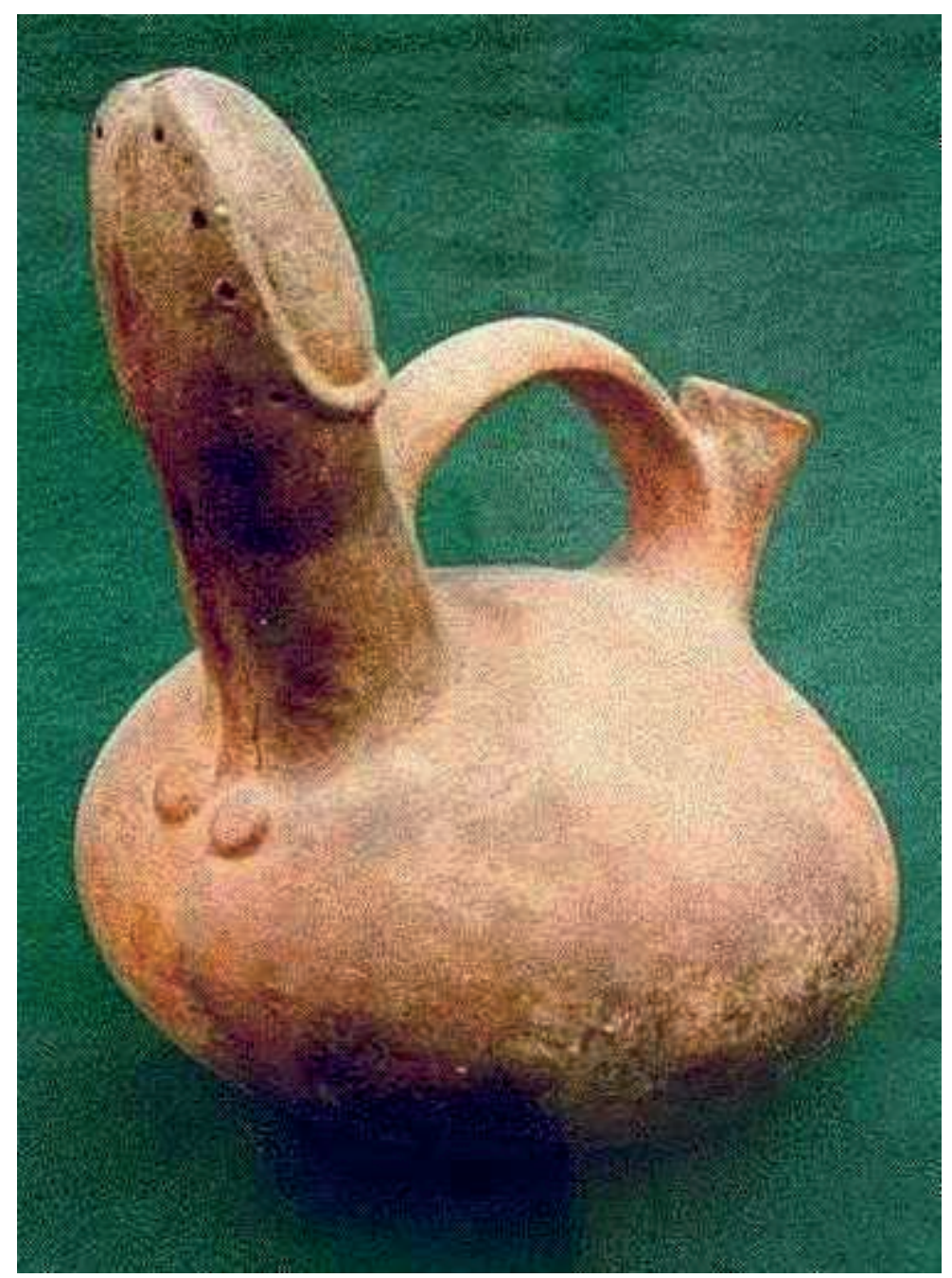

Figura 7c. Curiosa botella con Forma Fálica de Cultura Vicús. Los predecesores del arte erótico mochica. "Museo Nacional de Arqueología, Antropología e Historia del Perú". (MNAAHP) Lima.

\subsection{Un Eros arácnido... y una teoría sobre el fin de los mochicas}

Resulta lógico suponer, pues, que el arte erótico de este periodo se desarrolló bajo las concepciones imperantes de la época, asociadas a las ideas religiosas y filosóficas de los mochicas, quienes creían que no todo terminaba con la muerte (tesis abonada por el hecho de haberse hallado esqueletos que estaban dispuestos en una postura harto 
sugestiva, como si estuvieran teniendo relaciones sexuales "post mortem"), y que una de sus divinidades, el llamado Ai-Apaec, también conocido como "Degollador", era el centro del poder fecundador y procreador de vida, además de ser el dios más influyente en la vida cotidiana de este pueblo.

El "Degollador" era una especie de araña antropomorfa que es representada en las pinturas murales con una expresión atemorizante; era un extraño ser con rasgos claramente eróticos. Se trataba de un dios dual singularmente ambiguo y contradictorio, pues mientras por un lado procreaba la vida, por el otro la destruía. Fue una divinidad que por siglos simbolizó la abundancia y la riqueza, el mismo que, tal como se desprende de los últimos hallazgos en la zona del valle de Moche, parece haber terminado "su hegemonía" covertido en sinónimo de muerte.

Desde 1996-97, un equipo de especialistas de la Universidad de Trujillo (40), dirigido por el arqueólogo peruano Santiago Uceda y el restaurador Ricardo Morales, con el apoyo de un equipo francés, vienen trabajando en el estudio y puesta en valor de los restos arqueológicos Mochica. Al pie de los grandes complejos ceremoniales Mochica, como la "Huaca de la Luna" (17) (Nota 8) y el complejo denominado "El Brujo", en Santiago de Cao, al norte de Trujillo, este afanoso grupo humano encontró inmensos murales coloreados con decenas de representaciones del "Degollador", personaje también conocido como "dios araña". Y en los alrededores de estos recintos sagrados, los arqueólogos descubrieron algo que les erizó los pelos. 


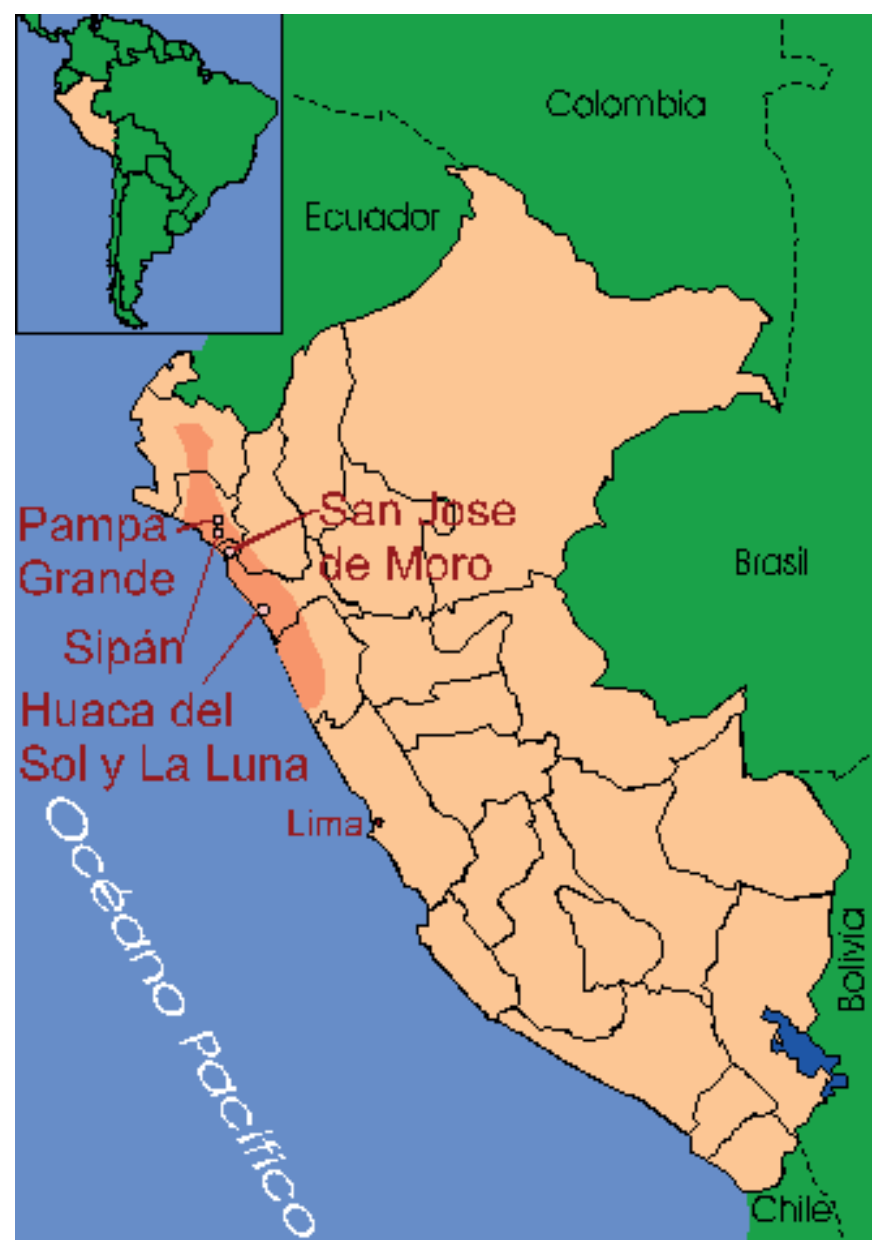

Figuras 8a. - 8b. Mapas general y detallado del reino Moche. Se extendió a lo largo de la costa y sierra septentrionales del Perú, y tuvo influencias culturales mas allá de sus fronteras por el norte y por el sur. Algunos investigadores aseguran haber encontrado las huellas de un intenso intercambio comercial entre los mochicas y culturas centroamericanas. Portal "Culturas Preincaicas - Moche". 

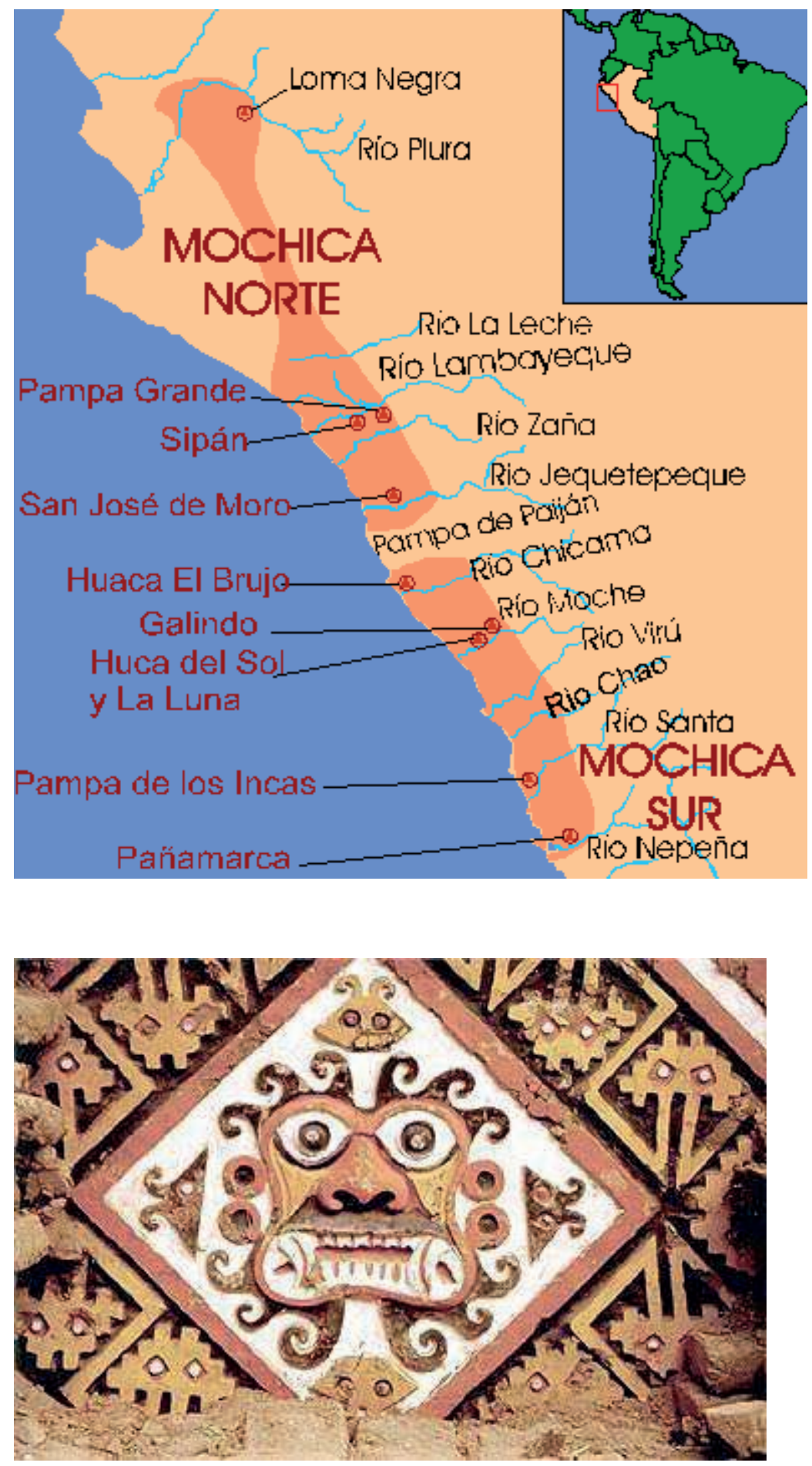

Figura 8c. El "Degollador", un dios terrible y enigmático. En los últimos años se han descubierto innumerables frescos murales de esta deidad con forma de araña que debió haber sembrado el pánico en todo el norte peruano -unos ojos vivos y 
sedientos de sacrificios humanos flanquean una boca enorme con colmillos de felino - y cuya presencia marcó el auge y el declive de la civilización Mochica. Fresco del friso de la "Huaca de la Luna". Foto del "Patronato Huacas del valle de Moche" (Perú).

Esto era lo que arqueólogos como Julio C. Tello o Rafael Larco Hoyle jamás habían sospechado: restos humanos depositados en posición fetal dentro de fosas comunes. Los esqueletos iban desde niños hasta ancianos, hombres y mujeres, y tenían el cráneo destrozado, sin duda a mazazos. Al parecer se trataba de víctimas de verdaderas matanzas rituales. Así se corroboró lo que era un rumor lejano, que los sacerdotes moche habían instaurado una teocracia en la que se ofrecían sacrificios humanos en honor de sus siniestros dioses, particularmente para el "Degollador". Matar personas frente a las imágenes del "dios araña", en solemnes ceremonias, era la base de los ritos sociales y religiosos de esta deslumbrante pero desconcertante civilización.

Otra evidencia arqueológica es el hecho de que, en un momento determinado de la historia mochica, tales sacrificios humanos parecieron haber aumentado de forma alarmante. Esto lo corrobora la cantidad de restos óseos descubiertos en las cercanías de los centros ceremoniales, especialmente los dedicados al culto del terrorífico "Degollador", como la "Huaca de la Luna". Así, la ciencia se topó con uno de los mayores misterios arqueológicos del antiguo Perú. Ante el panorama desolador con que se tropezaron los investigadores al iniciar las excavaciones, en lo que fue la capital de los moches -una zona urbana ubicada entre las dos grandes huacas del valle de Moche, la de la Luna y la del Sol, cerca de Trujillo-, no pudieron dejar de señalar que algo terrible había sucedido en aquel lugar. ¿Por qué? se preguntaron algunos. 
Para tratar de entender la razón de este enigma, y basándonos en los hallazgos recientes y cruzando informaciones, nos hemos permitido esbozar una teoría sobre los últimos días de esta cultura. La pregunta es: ¿Cuál fue la causa del final de los Mochicas? La respuesta habría sido la desesperación por la falta de agua y alimentos. De alguna forma, por paradójico que parezca, los muertos de Moche comenzaron a contar su triste historia. Entre los siglos VIII y IX de nuestra Era llegó a estas tierras uno de los fenómenos climáticos más devastadores que se recuerde. El estudio de la climatología en la costa peruana, en los últimos milenios, avalado por los hallazgos arqueológicos, demostró que durante varios años el fenómeno de "El Niño" provocó una terrible sequía en el norte del país y lluvias con inundaciones en el sur. El embate de la naturaleza coincidió con un periodo crucial en la historia de los moches, cuya civilización ya mostraba signos de decadencia.

El hambre y las carencias más elementales, provocadas por la sequía, habrían dado lugar a graves disturbios sociales y, probablemente, también una revuelta de orden político-religiosa. Acosados por el pueblo y el hambre y presionados por su clase sacerdotal, los dirigentes mochicas atacaron a sus vecinos sometiéndolos por las armas y por el miedo a sus dioses, para tomar prisioneros... Después, a exigencia de sus sacerdotes, sometieron a su propia gente con el fin de sacrificarla para que el cielo les devolviera el agua y la comida. Y la desesperación de los sacerdotes provocó un verdadero desastre demográfico -presumiblemente también una gran migración de mochicas huyendo de la crisis y de sus sacerdotes-. Por allí se dice, tal vez no sin razón, que este sangriento culto al "Degollador", por ser éste considerado el procreador de la vida, y un fenómeno climático inusual pudieron haber marcado el fin de esta cultura. Los viejos templos de esta siniestra deidad de terribles colmillos terminaron llenándose de muertos de forma desproporcionada. El caos y la anarquía se extendieron por todo el país. La población, seguramente cansada de los abusos de la clase dominante, se levantó contra semejante teocracia. Conclusión: un dios erótico y un fenómeno meteorológico de grandes proporciones se habrían confabulado para 
acabar con una civilización brillante cuyas creaciones artísticas nunca pudieron ser igualadas, aunque sí malamente imitadas.

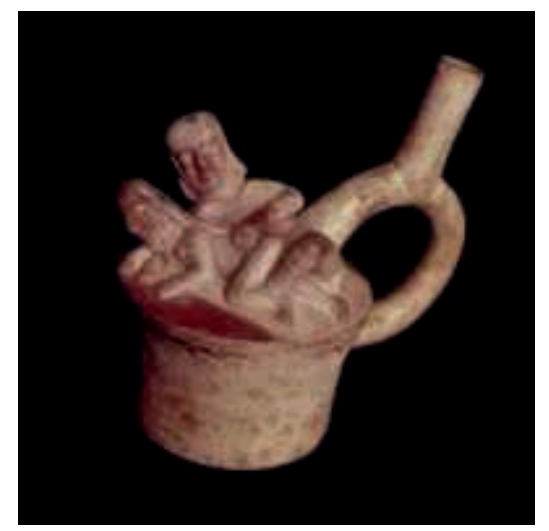

Figura 9a. "Vasija cubicular con aplicaciones antropomorfas. Pareja durante el acto sexual". Ceramio con asa estribo y vertedera. Cerámica pintada con aplicaciones 16.8 alto x 18 ø mayor.480 gramos. Cultura Mochica. Periodo Auge. Esta pieza formó parte de la exposición temporal "Ofrendas funerarias y arte erótico en el Perú antiguo", organizado por el "Museo Nacional de Colombia". Bogotá, diciembre 2000 a febrero 2001.

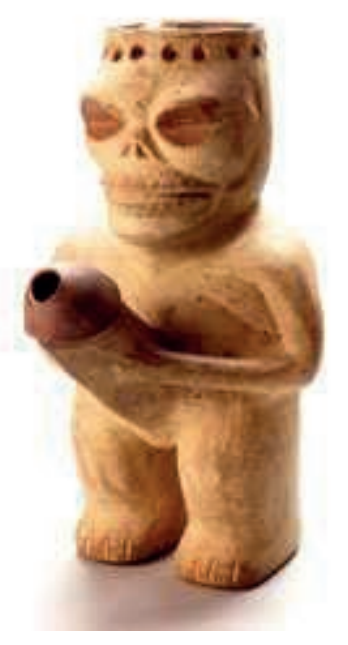

Figura 9b. Idolillo que representa a un hombre con prominente miembro viril. Cultura Mochica. 1 - 800 D.C. Época: Auge. "Museo Larco", Lima, Perú. 


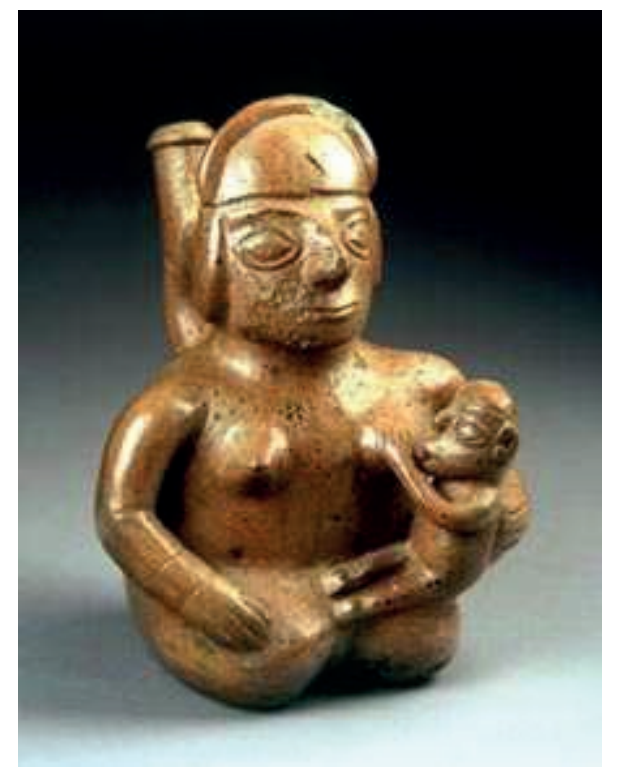

Figura 9c. "Botella escultórica realista representando a mujer amamantando a infante". Cultura Mochica. 1 800 D.C. Época Auge. "Museo Larco", Lima, Perú.

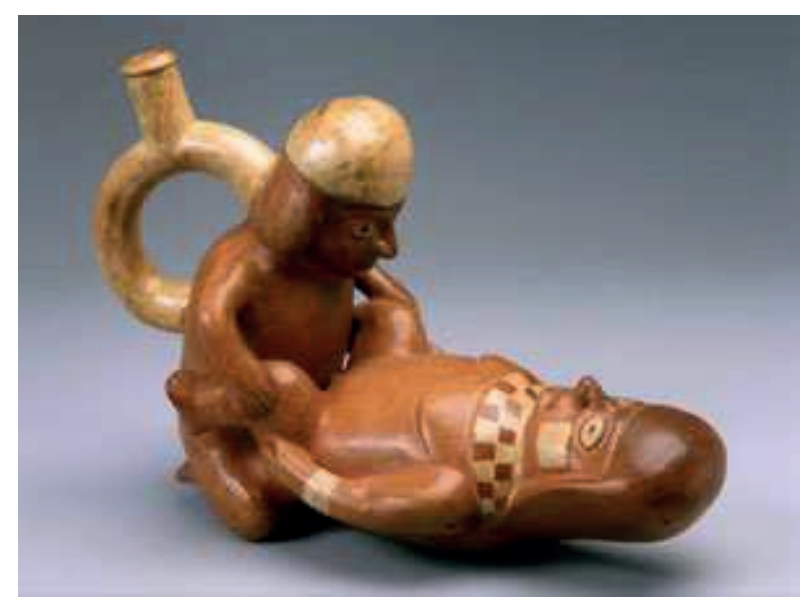

Figura 9d. "Botella escultórica realista representando escena sexual entre hombre y mujer". Cultura Mochica. 1 - 800 D.C. Época Auge. "Museo Larco", Lima, Perú.

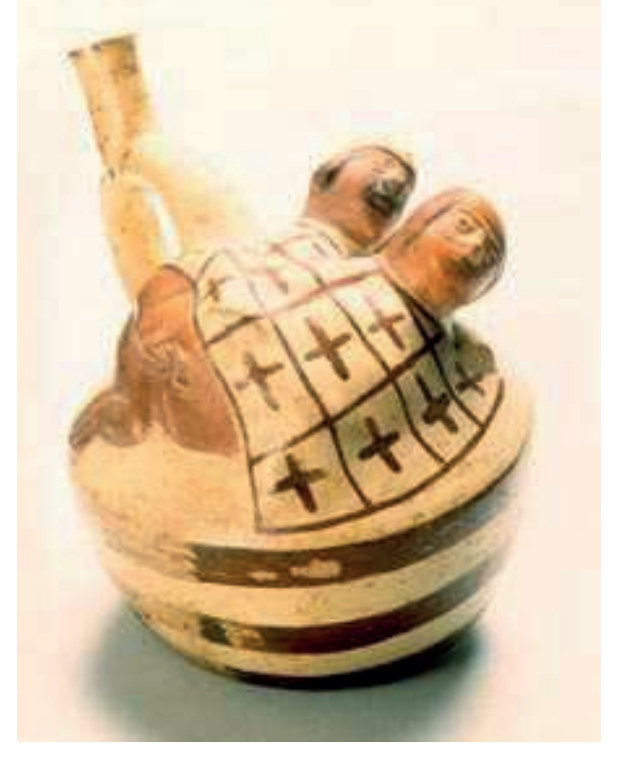

Figura 9e. "Botella escultórica realista representando escena sexual entre hombre y mujer". Cultura Mochica. 1 - 800 D.C. Época Auge. "Museo Larco", Lima, Perú. 


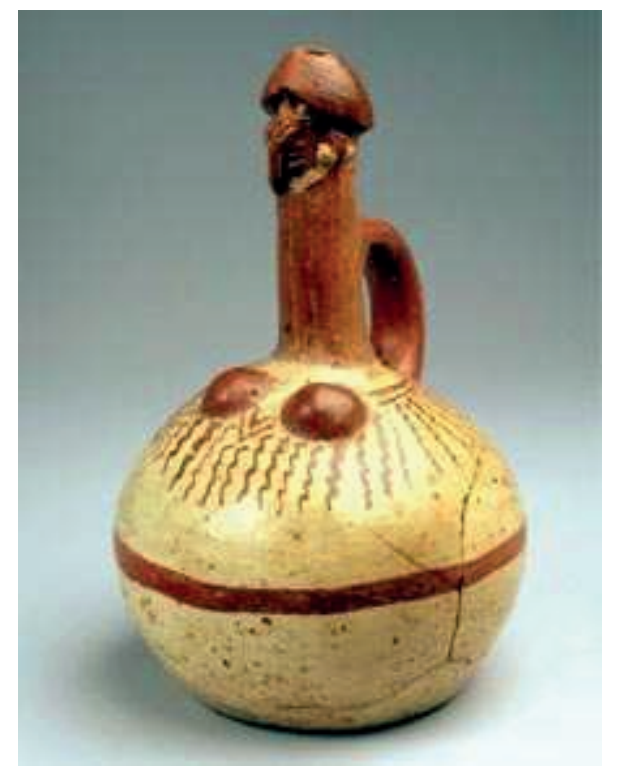

Figura 9f. "Botella escultórica humorística representando genitales masculinos". Cultura Mochica. 1 - 800 D.C. Época Auge. "Museo Larco", Lima, Perú.

\section{La historia "inexistente"}

"En este aspecto, los Cronistas nos han dejado prácticamente la única fuente histórica de información acerca de lo que aconteció en el incario. Con sus crónicas comienza básicamente la Historia del Perú. Están basadas en lo que vieron y en las tradiciones, descripciones de hechos, mitos y relatos, en su mayor parte a través de segundas o terceras bocas."

"Estas Crónicas en lo relacionado con el tema que nos ocupa, han sido criticadas, por los prejuicios o tabúes religiosos y morales con que venían embebidos sus autores."

Enrique Fernández (13).

\subsection{Enfoque moderno de un viejo asunto}

En la historia del Perú, las fuentes escritas no le han hecho ningún favor a las viejas culturas andinas previas al incario. Es una página en blanco de nuestra historia. Por 
tal motivo, la arqueología siempre se ha tropezado con "nada" cuando se trata de hacer investigación documental y ha tenido que hurgar casi a ciegas, y partir de "evidencias físicas", para poder hilvanar un confuso rompecabezas entre un montón de ruinas. La falta de libros o escrituras, peor aún, las casi nulas referencias directas de estos pueblos, conspira contra todo intento de comprender el pasado preinca. Tan sólo se puede contar con informaciones indirectas e imprecisas que pasan por el tamiz de los incas y de los mismísimos españoles, todas recogidas durante la época de la Conquista y periodo colonial (siglos XVI - XVIII). Después de la Conquista, sólo los curas católicos parecían interesarse en los pueblos indígenas... pero únicamente para "evangelizarlos" o extirparles las "idolatrías" o, peor aún, para imponerles la Inquisición. Poco se interesaron por su cultura o sus costumbres o su historia.

El estudio de las sociedades preincas es, pues, un tópico de difícil resolución para los investigadores. La existencia de estos pueblos anteriores a los incas poco pareció importarles a los Cronistas de la Conquista -que por un lado estaban alucinados por el mundo inca y, por el otro, imbuidos de los prejuicios y estereotipos propios de su época, traídos de la península Ibérica, lo que seguramente les impedía ver otras realidades - . Esto es lo que parece dar a entender el doctor Enrique Fernández (13), conocido psicólogo y catedrático de la Facultad de Psicología de la Universidad Peruana Cayetano Heredia (14), fallecido en 2002, quien hizo varios trabajos sobre el comportamiento humano relacionado con la sexualidad. En un país como el Perú, donde hablar del asunto, así sea relacionado con la arqueología -o el arte, en el más puro sentido de la palabra - , es casi un tabú absurdo, Fernández tuvo el coraje de encarar públicamente el tema y ponerlo en Internet. En su ensayo "La Sexualidad en el antiguo Perú" (13) denuncia la ceguera e indiferencia académica existente sobre este tema tan importante para conocer el cómo éramos en otras épocas. Aquí este autor indica que investigar las relaciones sexuales hombre-mujer en el antiguo Perú es fundamental para comprender la complejidad conductual de estas gentes, pero que también es uno de los "acápites" de la ignorancia histórica, casi patológica y 
muchas veces adrede, que ha existido y existe en torno a la vida y costumbres de nuestros pueblos aborígenes. Es como una "amnesia" a sabiendas que se extiende sobre todo en las altas esferas intelectuales de nuestra sociedad, particularmente en Lima, y especialmente entre los llamados "expertos" en la materia, justamente quienes más discriminan la actualidad de esta realidad histórica, aunque no lo digan; ellos, de una u otra forma, han insistido en mantener ese "silencio solapado" para que el vulgo no se entere de ciertos aspectos de nuestro pasado precolombino, como es el caso de los huacos eróticos que son escondidos en nuestro principal museo de arqueología, algo que no se ve en otras latitudes, como es el caso de Europa, donde estas manifestaciones de la creatividad humana forman parte de su acervo cultural y no son rechazadas ni ocultadas o disimuladas como ocurre en el Perú. Se trata de un comportamiento muy típico de los peruanos, salvo honrosas excepciones, que penosamente son muy escasas. Es una actitud negativa hacia el Perú preincaico que se ha venido gestando desde hace siglos tal como señala entre líneas el doctor Fernández cuando dice que... "existen referencias escritas, historias, leyendas y tradiciones frescas de la época incaica y muy escasas representaciones artísticas de la cerámica que conocemos con el nombre de huacos." Pese al tiempo transcurrido y a los hallazgos recientes que han cambiado nuestra perspectiva sobre culturas como la Mochica o Paracas, esta actitud negativa es mantenida a toda costa en los corrillos científicos peruanos; dando la impresión de que a alguien parece avergonzarle que existieran estos pueblos y el tipo de arte que crearon. Vergüenza en realidad ajena, pues los "especialistas" la miran desde lejos y no la tocan; seguramente les va a salir roncha ..."

Según Fernández, los cronistas sólo se remitían a los Incas y a los hechos acaecidos en la primera mitad del siglo XVI. Y si hablaban de estos pueblos, lo hacían refiriéndose a las conquistas de los reyes cusqueños -pero poco o nada de la vida del pueblo, los verdaderos protagonistas de la cultura andina-, por lo que Fernández afirma, no sin razón, que en el siglo XVI, con las Crónicas escritas por autores como 
el Inca Gracilaso, Betanzos o Cieza de León, es cuando recién "comienza básicamente la Historia del Perú", añadiendo además que esta historia o historias están basadas únicamente en lo que vieron y en las tradiciones, descripciones de hechos, mitos y relatos, en su mayor parte procedentes de fuentes indirectas, como por ejemplo lo que escuchaban de segundas o terceras personas o testigos de hechos diversos. Vale decir, los cronistas de indias escasamente tuvieron contacto directo con los hechos descritos en sus obras, y esto con el agravante de que en ninguna parte de la geografía andina, muy al contrario de lo que sucedió en México, se encontró alguna forma de escritura. Por tal motivo, no extraña la insistencia del autor en mencionar que los cronistas y después los investigadores (arqueólogos, antropólogos, etc), sólo se han podido basar en otro tipo de testimonios del pasado... "Estas crónicas, en lo relacionado con el tema que nos ocupa -prosigue Fernández-, han sido criticadas por los prejuicios o tabúes religiosos y morales con que venían embebidos sus autores."

Más abajo, hablando del asunto de los prejuicios, el autor recuerda que por 1517 llegó a América la temida Inquisición, lo que contribuyó a enturbiar las cosas, pues "... se niega autoridad a los Cronistas para opinar imparcialmente, ya que en ciertas cosas se les considera que toman partido con la cruz y la espada como base de la política del Estado español, a más de sus intereses individuales o de grupo."

Esta situación es lamentada por el peruanista Raúl Porras Barrenechea, quien es citado por Fernández, cuando escribe: "Con relación a esto, con la flexibilidad que da la lógica, recurro a Porras Barrenechea quien escribe: "Las crónicas de la conquista son la primera historia peruana... la leyenda y el mito, la simple tradición oral de los pueblos primitivos son fuentes remotas de la historia, pues no la constituyen todavía. La historia puede apropiarse de ello pero, por su índole, ella es esencialmente prosa y no poesía... La historia aclara la conciencia de los hechos, y da al hombre la capacidad y la necesidad para comprobarlos" (15). 
En esta situación, para infortunio nuestro y de los pueblos que vivieron por estas tierras antes de los incas, ignoramos casi todo acerca del pasado preincaico, sólo por los restos materiales y las leyendas y tradiciones, muchas veces deformadas, sabemos que existieron. De este larguísimo periodo de la historia en blanco, de más de diez mil años, sólo tenemos representaciones artísticas, escultura, cerámica, dibujos y pinturas rupestres o en muros que nos muestran cómo era su mundo e incluso su vida sexual...

"Carecemos de otras fuentes -vuelve a lamentar Fernández-, no hay que olvidar que entre mochicas e incas hay un milenio o más años de separación." Pero añade que la historia de los incas parece ser mucho más realista, e incluso más exacta que la tradición oral de otros pueblos primitivos -puesto que los cronistas de la Conquista, como Pedro de Cieza o el Inca Garcilaso de la Vega, los conocieron, y ser testigos de esa historia viviente, en cierta forma, ayudó en algo a que ese pasado lejano no se esfumara por completo, gracias a que las crónicas e historias, amén de leyendas y tradiciones, recogidas por los cronistas, permite vislumbrar la coexistencia de los incas con ese pasado que heredaron o adoptaron por la vía de sus conquistas - . De este modo, la eficacia de la historia de los incas, recogida por los autores de los siglos XVI y XVII, "está demostrada en que, mientras en otros pueblos la tradición oral sólo alcanzó a reconocer hechos de 150 años atrás, la historia incaica pudo guardar noticia relativamente cierta de los nombres y los hechos de dos dinastías, en un espacio relativamente mayor de cuatrocientos años."

\subsection{Condenando el pasado}

Tal carencia de testimonios escritos acerca de los pueblos preincaicos del antiguo Perú, y la imprecisión de muchas de las tradiciones orales que recogieron tanto los cronistas como autores que siglos después se interesaron por el pasado peruano, es comparado por el autor con el presente desconocimiento del real comportamiento 
sexual de los peruanos actuales, lo que demuestra el desinterés de los investigadores para encarar este problema; aunque reconoce que "... existen algunas encuestas, tesis y otros trabajos parciales acerca del tema, en general, ya sea en libros, revistas y diarios (...). Pero creemos -insiste - existe una fuente histórica que aún no ha sido explorada in extenso."

Y añade, al respecto, cuando habla de los usos y costumbres de los indígenas peruanos, que hubo un mestizaje en el Perú que empezó el día en que Colón arribó al Nuevo Mundo, y que a partir de esa fecha se extendió por todo el continente "sin inconvenientes, debido a que: "si el español católico le tenía miedo al agua -como sostiene José Gil Fortaul - jamás se detuvo ante las mujeres de raza diferente, fueran moras, judías, negras o indias." De esos usos y costumbres, por lo menos en parte, procedemos la mayoría de los peruanos".

Entonces, como corroborando lo señalado en el subcapítulo anterior (3.1.), y no sin razón, nos preguntamos... ¿por qué los peruanos de hoy insisten en negar su pasado lejano? ¿Qué nos hace no aceptar que muchas de nuestras costumbres provienen de las culturas que nos precedieron, incluyendo la inca, que adoptó muchas de sus formas de ser de otros pueblos? Esta negación, pues, ha sido el factor que ha conspirado contra el conocimiento de nuestras raíces, un mal que parece haber contagiado incluso a la arqueología peruana, en cierto grado, pues ésta no considera como evidencias ciertos aspectos o rasgos del comportamiento humano en las culturas pretéritas. "Creo sí -trata de explicar Fernández - que es importante señalar algunos aspectos del conocimiento del indígena peruano imbuido en su cultura." Tal como alude el doctor Fernández, con quien concuerdan otros autores como Porras Barrenechea y los cronistas de los siglos XVI y subsiguientes, ¿no sería lícito, entonces, preguntarnos, si no es casual que en el seno de nuestra sociedad peruana, sobre todo entre los estamentos más influyentes -en particular de los académicos y los "expertos", que no parecen ver más allá de su ego, de sus escritorios y de sus 
títulos y grados universitarios, y de los esquemas mentales retrógrados de quienes manejan un sistema educativo oscurantista, alienante y descaradamente sesgado-, exista una negación solapada de nuestras raíces -tamizada por una suerte de indiferencia institucionalizada - , es más, que se pretenda pasar por alto -o, lo que en el argot peruano se dice, "echarle tierrita y olvidarse del asunto" - ciertos aspectos inherentes a las culturas precolombinas, a los usos y costumbres de sus gentes, las mismas que hemos heredado de alguna $u$ otra forma, y que ahora son parte de nuestra forma de ser, incluyendo la sexualidad? Lo único cierto es que, pese a tal negación, algo de las culturas andinas precolombinas quedó impreso en nuestros genes, en nuestra propia idiosincrasia; de ellos, injustamente cualificados como "yndios", al decir de los cronistas, hemos heredado o adoptado un bagaje cultural o racial que configura nuestro actual "modus vivendi". Y de esto nada nos libra, ni siquiera la indiferencia académica que pretende negarla. Se trata de una realidad que nos ha sumergido en la ignorancia de nosotros mismos.

En otro acápite, el autor se refiere a esa ancestral costumbre que adoptaron los incas, el llamado "servinacuy" (ver capítulo 5. El servinacuy, matrimonio "de a mentiras"), que durante la colonia fue tan combatida por la Iglesia Católica, institución cuya desafortunada política "extirpadora", en vez de erradicar esta práctica, lo que provocó fue un verdadero trauma social entre los pueblos andinos, al punto de generar una mezcla de repudio y aceptación solapadas. La presión ejercida por los curas católicos se tradujo en la rebelde actitud de muchas comunidades de los Andes, donde todavía se insiste en practicar esta ancestral costumbre contra viento y marea, al extremo de perder su verdadero significado, convirtiéndose en un verdadero libertinaje sexual, cosa que no habrían permitido los incas.

Sobre este aspecto, debemos recordar que junto al "servinacuy" había otras costumbres también practicadas por incas, que también criticaron y persiguieron los españoles. Prácticas, como el "misqui", el "tincunacuy", el "tincunacuspa", el "seriasi", 
el "topacashca", el "yachanacuy", el "pantanacuy" o "pantanaco", llamado también "matrimonio de prueba", como el servinacuy (Nota 7). El deseo de erradicar estas costumbres fue tal que, cuenta Fernández, "el virrey Toledo, en 1575, promulgó unas ordenanzas al respecto contraviniendo la Cédula Real del 4 de Septiembre de 1560, que prohibía tener en los "monasterios cepos (ni en ninguna parte) para poner en ellos a los indios, indias que quieren, y aprisionan y azotan por lo que les parece y los trasquilan, que es un género de pena que se suele dar a los indios, lo cual ellos sienten mucho".

He aquí unos párrafos de las ordenanzas VIII y XIV, del Virrey Toledo: ... "Por cuanto hay costumbre entre los indios, casi generalmente, no casarse sin primero haberse conocido, tratado o conversado algún tiempo y hecho vida maridable entre sí ... ordeno y mando que se procure, así por los sacerdotes, corregidores, caciques y alcaldes persuadir y quitar a dichos indios esa costumbre tan nociva y perniciosa... El indio cristiano que tuviese acceso con india infiel o estuviere amancebado con ella, por la primera vez, que lo trasquilen y den cien azotes; y por la segunda lo remitan preso con la información al Corregidor, para que lo castigue conforme a derecho..."

También prohibió al aborigen tener a su lado a "hermana suya", ni cuñada, ni tía, ni primera hermana, ni manceba de su padre, siendo las tales de menos edad de cincuenta años abajo... que ninguna india moza, ni viuda sirva ni de beber a su hermano, ni cuñado, ni tío, ni primo, siendo de cincuenta años para abajo..." so pena de los cien azotes y trasquila y que sirvan dos años en los hospitales".

Anecdóticamente no está demás señalar que en el "Runa Soncco", periódico que editaba en Juliaca el pionero de la Salud Pública en el Perú, Manuel Núñez Butrón, están las participaciones o avisos en la Crónica Social en la que se comunicaba que fulano y zutana "entraron en servinacuy" o que lo terminaban o se casaban. 
Villavicencio (61) le dedica a esta costumbre interesantes páginas y la lucha estéril por erradicarla durante el virreinato.

Así el Concilio de Lima de 1582 lo condenó y dio disposiciones para terminar con esa costumbre que ahora la practican en gran proporción los habitantes del primer mundo, abierta, indiferente o solapadamente".

\subsection{Al encuentro del origen "perdido"}

Dentro del contexto de las sociedades precolombinas peruanas, Fernández no tiene la menor duda sobre el origen preincaico de algunas costumbres sexuales posteriormente adoptadas por los incas y que después llegaron con muchos cambios hasta nosotros como comportamientos y actitudes. Y señala que en la cerámica preincaica están muchas de las respuestas acerca de dónde venían, quiénes eran, cómo eran y cómo vivían y morían, e incluso se puede saber la historia ignota de los hombres y mujeres de estos remotos tiempos. Este autor insiste, pues, en que las fuentes escritas de diversos autores nos pueden llevar hasta una pista, un camino que nos muestra aspectos desconocidos de nuestro pasado, y que los llamados "huacos eróticos", la increíble cerámica que tanto asombra a los expertos, son el mejor testimonio acerca de la intimidad de los antiguos peruanos. Son evidencias arqueológicas que nos permiten conocer mejor ese pasado que muchos se obstinan en negar o reconocer. Por esta razón, el autor nos remite a estas fuentes y al arte erótico, ya que hasta ahora nadie ha encontrado aún evidencia de algún tipo de escritura preincaica, de modo que resulta necesario recurrir a tales elementos para averiguar lo que de orta forma sería imposible.

Por tal motivo, hemos creído conveniente insertar aquí el íntegro de una parte de este ensayo, donde el autor hace unas reflexiones y consideraciones muy interesantes. 


\subsubsection{Consideraciones "non sanctas"}

"Menos citado es el estudio de Terrazas Contreras ( ) que manifiesta que su investigación "tiene el mérito de haber sido el primer trabajo sistemático sobre el particular, en 100 años de arqueología peruana".

Opina que "la preincaica de la costa norte del Perú... se sumergió en el completo hábito del sexo, plasmando sus más íntimas vivencias, muy lejos de prejuicios y tabúes aún actuales..., que fue precisamente el amor lo que sublima toda actividad vital en el habitante del Perú antiguo", que el coito anal heterosexual era con fines de evitar la concepción y Cita a Varallanos, quien se refiere a dos máximos quechuas: "Ama Maclla" (no seas afeminado) y "Ama Mapa" (no seas invertido).

Entre los libros que he consultado resalta el del Obispo del Obispado de San Francisco de Quito "en que se tratan las materias más particulares, tocante a ellos (los indios) para fu buena Administración" que se titula "Itinerario para Parochos de Indios", en el Tratado X De los Misioneros, Session VIII p: 182, que se ocupa "Del cuidado que debe tener el Ministro Evangélico en quitar a los convertidos algunos vicios y pecados "expresando que El Predicador, y Maestro, que rige las almas de los que fon tiernos en la Fé, recién convertidos a Dios, ha de hazer con ellos lo que haze el buen hortelano, efcogiendo los mas fuaves, ni admirandofe, o enojandofe demafiado, porque en un dia no vea trocados en Catones, y Senecas unos Barbaros, ni transformados en Angeles unas bestias...

El primer vicio que ha de quitar es la fodomia, y bestialidad, porque como dizen Antonio de Herrera, hablando de la Ifla Española y de la Ifla de Corro, es muy comun entre aquellos Barbaros. Y Garcilafo Inga dize de los Indios del Perú, que eran muy dados al pecado nefando, y Fray Pedro Martyr, de cada 3. in Hiftoria Generali Indiarum, cap. 62, cuenta, que en la conquifta que hizo Blafco Núñez Balboa en la 
Provincia de Efcaraguan, halló tan manchada aquella tierra defte vicio, que muchos Indios eftavan veftidos en trage de mugeres, para denotar con el hábito fu torpeza, y fu, tanto lo que fe embraveció defto el Capitan, que quarenta deflos, que pudo coger a las manos, los echó a los perros, para que muriellen defpedacados, con admiración y gufto de los dems Indios.

El fegundo vicio, que le ha de arrancar, es la idolatría...

El tercer vicio, y más, dificultofo de arrancar, es la embriaquez... Lo quanto, fe ha de advertir, que les enfenen a veftirfe, y tratar sus carnes con honeftidad..... porque aunque la defnudez total no es intrinfecamente mala (como dize Santo Thomas)...

Americo Vefpufio dixo en la relacion que hizo de fu primera navegacion a las Indias, que entre efta gente bárbara la defundez total no era viciofa, porque no era provocativa a luxutia, pero como no fabia el interior de los coracones, no haze mucha fee fu dicho, cubriendo fus carnes con hojas de higuera luego que pecaron; y afii dize San Agustin: Si nihil in libidine illa ineffer pudendum.

Tambien es abufo comun entre los Indios, y que fe deve atajar, que las mugeres no eftima la virginidad ante nuptias, que en todas las Naciones del mundo fe refpeta y honra, mas antes la tienen por afrenta, y fe tien, por tan defdichadas, que ninguno las ha apetecido, como de los Indios del Peru lo dize Acofta... y affi las donzellas antes de cafarfe, llamaran al primero que toparan, para que las corrompieffe; costumbre infernal ...Defta coftumbre de la Gentilidad ha quedado hafta aora el abufo que tienen los Indios, de que no fe han de cafar menos que teniendo primero por algunos mefes trato malo con la que ha de deler fu muger, para faber por experiencia fi es a propofito para el matrimonio: eftas y otras coftumbres comunes entre Indios fe deven arrancar poco a poco, para que eche hondas raizes en fus coracones la Fé limpia, de los abufos abominables de la Gentilidad, pero el zelofo Miniftro del Evangelio fevaya 
co mucho tiento, no lo ha de querer acabar todo en un día; que fer echar a perder la cofecha, y dar con todo el edificio en tierra... Algo fe ha de diffimular, y paffar en filencio,. haciendofe diferentamente defentendidos en las faltas de gente tan barbara, que no es poffible menos de que tengan muchas, porque con el ufo de muchos años, y con el exemplo de tantos convirtieron en naturaleza el vicio; que afi lo hazia San Aguftin, con gente de mas capacidad, y Chriftianos más firmes que eftos indios". (16)

\subsubsection{Kinsey: una vista de médico a la arqueología peruana}

Creo que conviene recalcar que antes que la idolatría se coloca a la sodomía y al bestialismo como vicios que combatir.

Lógicamente Kinsey vino al Perú -lo hizo a fines de 1954 y visitó la colección de huacos de don Rafael Larco Herrera, que en esa época estaba en la hacienda Chiclín-. Ahí pudo observar centenares de huacos, considerándolos como el "más franco y detallado documento de costumbres sexuales jamás dejado por ningún pueblo antiguo".

Aquí su comentario: "Quiero estudiarla (la colección), porque aquí tenemos una documentación completa, sobria y realista de la vida sexual de un pueblo sin las inhibiciones que inhiben la vida sexual del pueblo de los Estados Unidos.

Los Mochicas no fueron condicionados en sus hábitos y actitudes sexuales por las costumbres, principios y prejuicios cristianos, como estamos nosotros. Mi investigación entre esos huacos me dirá más acerca de lo que es natural en el sexo, comparativamente, tanto como la investigación que llevo a cabo entre el hombre y la mujer Americanos" (3). 
Cuidadosamente, recalcó que no sacaría conclusiones acerca de las costumbres tradicionales y maneras de actuar de los Mochicas, dado que sus estudios estaban centrados en la vida sexual de los norteamericanos modernos.

La visita de Kinsey fue realizada junto con el Dr. Paul H. Gebhard y el fotógrafo William Dellemback. A la muerte de Kinsey, Gebhard asumió la dirección del "Institute for Sex Research", a la vez que era Profesor de Antropología de la Universidad de Indiana. El estudio que hizo Gebhard de los huacos con motivos sexuales de las colecciones de Larco Hoyle, el Museo Nacional de Arqueología y Antropología, el Museo Prado y el Museo de Trujillo, la Colección Wassermann-San Blas y otras privadas, se basó en un total de unos 800 huacos de las culturas Vicus, Salinar, Gallinazo, Nazca, Maranga, Recuay, Moche, Tiahuanaco, Huaura, Huari, Ica, Lambayeque, Chancay, Chimú, Chimú-Ica e Inca. La versión traducida que hemos utilizado es la publicada por el Dr. Denegri (24).

Volver al principio del apartado $\quad$ Volver al principio del artículo Volver al principio

\subsubsection{La humanidad de la arcilla I}

De esos huacos, el mayor número de especimenes corresponde a la cultura Moche con 450, le sigue la Chimú con 111, Lambayeque con 37, Chimú-Ica con 27, Vicus y Recuay con una docena.

De las otras culturas estudió contadas muestras. Señaló que de la Inca no hay cerámica representacional y si geométrica, concluyendo que esa cultura era contraria a las representaciones sexuales.

En el estudio que Gebhard hace, resalta lógicamente el de Moche, cultura que sabemos comenzó a desarrollarse del año 300 a.C. al 700 d.C., época en la que 
Alejandro Magno conquista Persia y Egipto. Acababan de morir Platón y Sócrates y todavía enseñaba Aristóteles. Al mismo tiempo, los galos saqueaban Roma y se construía la Gran Muralla China. Termina la Moche poco después de la entrada de Mahoma en la historia, en la época de Carlomagno. Abarca lo que los arqueólogos llaman Periodo Intermedio Temprano y la mitad inferior del Horizonte Medio.

El 8\% de los huacos de la cultura Moche corresponden a representaciones en que no hay actividad sexual manifiesta, como vasijas o artefactos que cumplen la función de cantimploras terminadas en glandes.

Gebhard clasifica como humorísticos a un 15\% de los huacos que sirvieron para que se bebiese el líquido que contenían; tenían que hacerlo por los órganos sexuales externos, especialmente por el pene. También hay un $4 \%$ de ceramios con penes enormes en general, que representan masturbación exclusivamente masculina. Nunca ha sido reconocida por ningún autor un huaco en que se represente una masturbación femenina. Uno se pregunta si es que también culturalmente, aquí, se hizo un escotoma del placer sexual femenino, como sucede corrientemente en muchas culturas.

En otro 8\% están las representaciones en que se muestran genitales exagerados en tamaño y a predominio femenino.

Es interesante anotar que los mochicas hicieron un reconocimiento cuidadoso del clítoris, hecho que no es usual en otras culturas tanto locales como foráneas.

\subsubsection{La humanidad de la arcilla II}

Existe un hecho que llama la atención. Es la presencia de personajes que unos llaman "cadáveres" los que por lo general representan a hombres que se masturban o 
manosean el órgano sexual de una mujer, o, no actúan cuando están en grupo de tres, no existiendo el de cuatro o más personas.

Tampoco encontró ceramios en que se representen caricias a las mamas, ni manuales ni bucales. Sí es curiosa la frecuencia de la caricia al mentón de la mujer por el hombre.

El 8\% de las piezas estudiadas representan la felatio. Pero llama la atención que hasta ahora no se ha encontrado la representación del cunnilinguis en la cerámica del Antiguo Perú.

No es de extrañar que el coito heterosexual fuera el tema más tratado por los ceramistas mochicas. Abarca el 39\% de los huacos estudiados por Gebhard. Le llama la atención el escaso número de posturas para ejecutar el coito, éstas son ocho, en las cuales no se representan por lo general más de dos personas.

En los casos en que hay un tercer personaje, ese parece que duerme y es una criatura, la que a veces mama normalmente de la madre. Estos representan la cuarta parte de este tipo de huacos. No encontró coitos de pie, ni sentados. La mujer está generalmente desnuda y el hombre con vestimenta. No hay besos ni caricias.

Los coitos son entre seres vivos y, en sólo dos casos, se representa al "hombre cadáver".

En suma el coito en estos casos, es esencialmente genital, sin manifestaciones faciales placenteras o de excitación, lo que no sucede en las representaciones de la masturbación,

En el 21\% el coito es anal, lo cual algunos explican como medida anticoncepcional. 
Gebhard y otros autores, se refieren a que hay sólo dos ceramios entre los cientos de estudiados en que se representa la homosexualidad masculina. La femenina, no se encontró.

Encuentra sólo un caso de relación sexual de una mujer con un ave, que por el tema recuerda a Leda y el cisne, que como se sabe fue tratado por Leonardo y otros artistas. Otro huaco que está en el Museo de Arte de Chicago representa a una mujer con un perro. Este caso Larco Hoyle lo discute y para él representa a una mujer atacada y derribada por el perro.

En cambio hay una gran cantidad de huacos de coitos entre animales, $27 \%$ son entre cuadrúpedos: Llamas y roedores, un 19\% entre sapos y criaturas que clasifica como mitológicas.

Entre estas representaciones hay autofelaciones en las que el personaje tiene un pene enorme.

La cultura Chimú dice Gebhard, "recogió la antigua tradición erótica de los mochicas", y en menor cuantía las de Huaura y Lambayeque.

En la Chimú, en un 50\% se trata de coitos heterosexuales, en que la mujer está en actitud pasiva, sin la representación de cadáveres.

Después de la conquista Inca todavía quedan rezagos de estas representaciones sexuales, para durante el imperio incaico desaparecer, posiblemente porque no quisieron recibir influencias de los vencidos. 
En el resto de las culturas, en las que Gebhard encuentra representaciones sexuales, en una buena parte, sólo se trata de desnudos o coitos, cuya descripción detallada creo que sobrepasaría los alcances de este artículo.

Por todo lo expuesto puede concluirse que por ahora es casi imposible tener una idea precisa del comportamiento sexual del antiguo habitante de lo que hoy es el Perú. Hace falta un estudio integral del tema, ya que no se trata simplemente de describir con palabras lo que se puede ver en los huacos mismos." (13)

\section{Templos de la fertilidad andina}

"Se mantienen de pie, algunos maltrechos o mutilados, otros indemnes y aún poderosos; pero eso sí, todos lucen atrevidamente erguidos, mofándose del pudor con su pétrea obscenidad y atrapando miradas por la audacia y desvergüenza de sus formas."

Rolly Valdivia Chávez (25).

\section{1. "Inca Ullu": los falos del Collao}

Hace miles de años, Europa y Asia también se vieron inundadas por representaciones gráficas en piedra o cerámica de las locuras de Eros. Así, el culto a la diosa Madre y la fertilidad fueron un común denominador entre pueblos como íberos, celtas y britanos, y aún de otros mucho más antiguos. Extraños templos edificados al aire libre y montículos artificiales fueron el escenario de curiosas formas de culto a la fecundidad y la fertilidad. Entre los alineamientos de Carnac, en Francia, los que se encuentran en la península ibérica o entre los menhires que se extienden por toda Europa central y del norte, además del archipiélago Británico y las mediterráneas islas de Malta, las Baleares, Córcega y Cerdeña, aún se alzan ciertas 
piedras que muchas veces llegan a superar largamente la estatura de un hombre medio y pesar varias decenas de toneladas, cuya existencia ha sido objeto de la polémica y las más diversas teorías acerca de su antigüedad, origen y la forma en que fueron colocados en sus actuales emplazamientos. La arqueología los llama "menhires fálicos" (Nota 9) por su forma tan evocadora... alargadas como columnas y con una especie de "sombrero", una suerte de prepucio lítico, en su parte superior; estos menhires se yerguen desde hace miles de años, al aire libre, como queriendo simbolizar una hipotética unión sexual entre el cielo y la tierra.

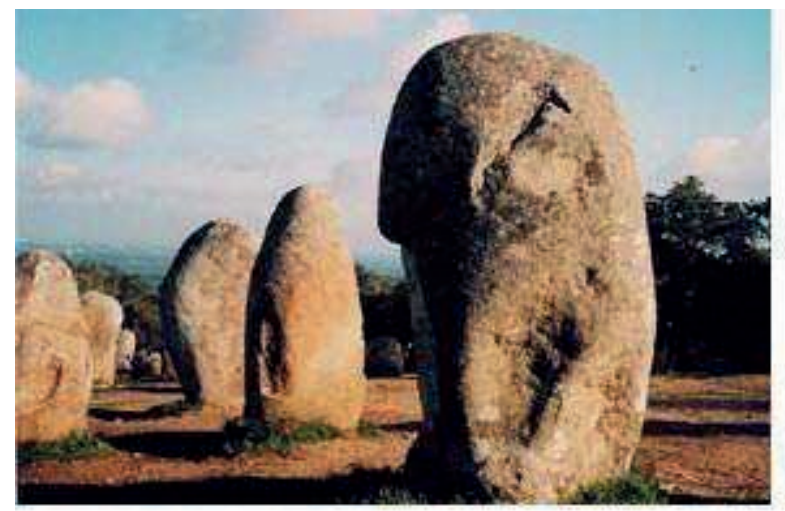

Figura 10. Menhires del conjunto megalítico de Evora (Portugal), complejo prehistórico hoy considerado como parte del Patrimonio Cultural de la UNESCO. Foto del portal de turismo de aventura "Bikeiberia.com".

Entre este paisaje tan común en la antigüedad europea y las montañas del Perú hay un trecho larguísimo para llegar al gran altiplano donde nos espera una sorpresa. Al otro lado del "charco", como le dicen los argentinos al Océano Atlántico, en el sur del Perú, en la región andina del lago Titicaca, en la ciudad de Chucuito, capital de la provincia peruana del mismo nombre, existe una extraña construcción que parece haber desafiado al tiempo y a los extirpadores de idolatrías de la época colonial. Se trata del llamado "Inca Ullu", también conocido como "Templo de la Fertilidad".

Esta construcción, de origen muy anterior a los incas, se levanta muy cerca de la iglesia principal de Chucuito, construida por los jesuitas en el siglo XVII, una circunstancia por cierto insólita pues en su interior unos 90 monolitos con forma de falo retan todavía el pudor público. Se trata de un templo donde la fertilidad se 
encuentra presente hasta en la puerta del recinto, que está flanqueada por dos pequeños falos. En lo que podríamos llamar "la nave" de este templo, decenas de estas piedras se extienden en todas direcciones. De vieja data, los lugareños, entre la burla y la superstición, han llamado a este recinto "Inca Ullu" o "Inca Uyo", que en la lengua aimara tiene el revelador significado de "miembro viril del inca", aunque es muy probable que a ninguna inca se le haya ocurrido entrar para sentarse allí, que sepamos...

Recorrer su interior es encontrarse con la magia ancestral del antiguo Perú. Los falos recorren la extraña "nave" y con su pequeño tamaño, como enanos, parecen rodear y adorar a su "hermano mayor", una inmensa escultura de más de un metro de altura que destaca en el centro de la estancia.

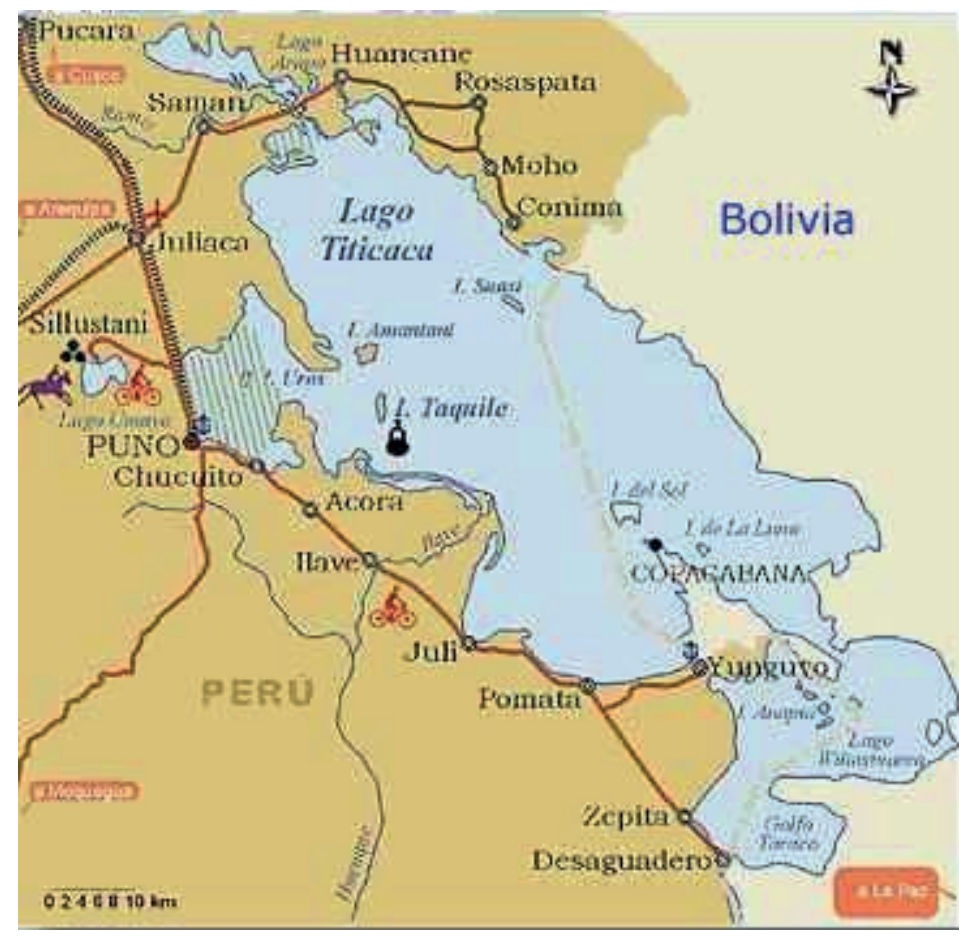

Figura 11a. Mapa de la región del lago Titicaca, donde se puede apreciar la ubicación de la ciudad de Chuchito, sede de esta extraña edificación. 


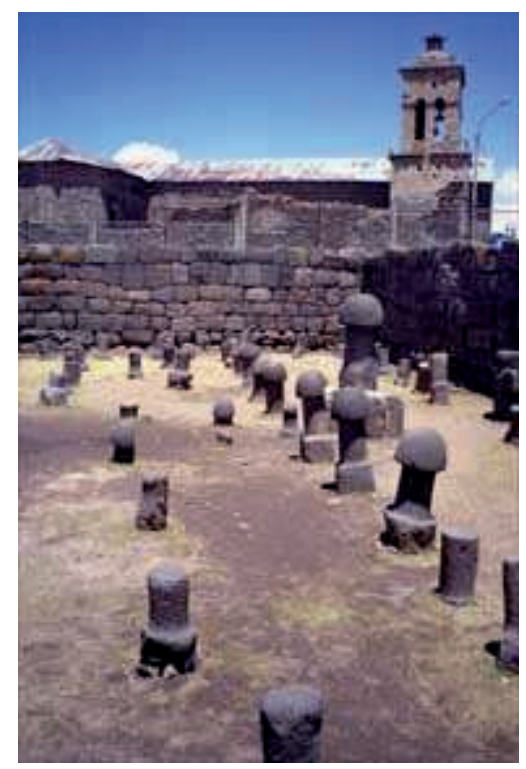

Figura 11b. Vista general del llamado "Templo de la Fertilidad" o "Inca Ullu", con la iglesia colonial de Chucuito al fondo. Foto del portal "Earthtravel.net".

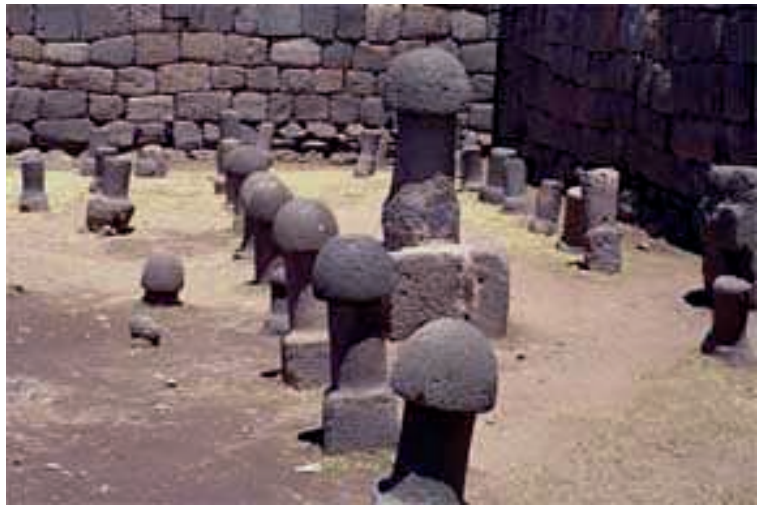

Figura 11c. Un detalle de este extraño templo. Según una tradición local, si una mujer estéril se sienta sobre una de estas piedras, tarde o temprano quedará embarazada, aunque esto no ha sido demostrado. Foto del portal "Earthtravel.net".

Más allá de cualquier consideración erótica, vulgar o púdica, los investigadores presumen que este edificio fue un lugar sagrado dedicado a la fertilidad, en el que se agradece a la naturaleza por el milagro de la reproducción humana. No falta quien atribuya también a este templo una forma de adoración a la Pachamama (Madre Tierra), donde se le rendía culto y se le pedía permitiera con sus frutos la prolongación de la vida. Y no era para menos, ya que en dicha región, la meseta del Collao, una inmensa llanura pelada, recorrida por ríos estacionarios y vientos helados, donde son frecuentes las sequías y las heladas que agostan las cosechas. 
Aunque parece incuestionable la connotación "erótica" de este lugar, las hipótesis sobre su verdadera utilidad varían. Mientras unos dicen que fue un recinto sagrado donde se realizaban ritos de la fertilidad, otros quieren darle atributos cósmicos al afirmar que, debido a la ubicación geográfica de Chucuito, habría sido un centro astronómico, mientras que, por su parte, los pobladores de esta localidad han otorgado una visión más terrena del asunto: para ellos se trata de un remedio eficaz contra la esterilidad, pues, según cuentan, si una mujer estéril se acerca y toca una de estas piedras, pronto quedará embarazada...

\subsection{Q'enqo, otro adoratorio de la fecundidad}

Es tal vez uno de los lugares más sorprendentes del Perú antiguo, no tanto por el simbolismo ritual que le dieron los incas -mitad culto al agua, mitad culto a la fertilidad -, sino por la forma de su extraña construcción. Ubicado a 4 kilómetros al este de la ciudad del Cusco, Q'enqo o Kenko es un complejo pétreo muy visitado por los turistas que acuden atraídos por la resonancia mágico-telúrica de este lugar. Mientras algunos arqueólogos dicen haber identificado en esta roca a un sapo invertido, cuya "panza" se encuentra surcada por canales que descienden por todas partes hasta el suelo, escaleras en zig-zag y un anfiteatro en el que están dispuestas 19 hornacinas a modo de asientos, otros dicen que se trata de un puma, animal sagrado de los Incas. En su interior, una curiosa galería semisubterránea, que se hiende en la roca bifurcándose en distintas direcciones, hace las delicias de los amantes de lo insólito y misterioso. 


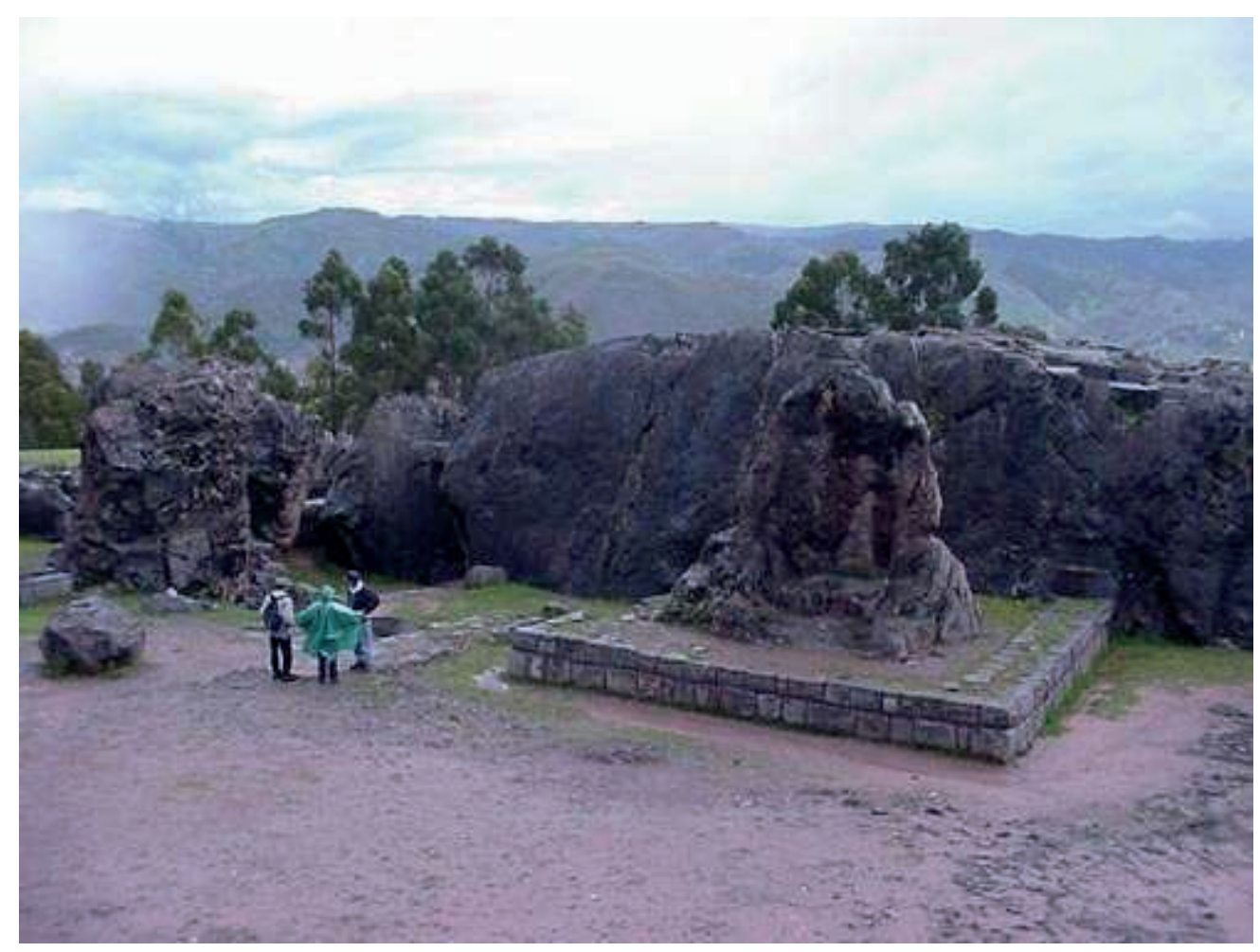

Figura 12. La extraña roca "invertida" de Q'enqo, cerca al Cusco, aún genera controversia. Para unos es un templo para ritos de agua, para otros era un lugar relacionado con la fertilidad. Foto del portal "Giro2000".

Este recinto pétreo ha sido descrito incluso por los cronistas de la Conquista como un lugar sagrado de los incas. Pero tal vez la estructura que más llama la atención en este complejo es un gran pedestal de piedra sobre el que se asienta una piedra semitallada, de forma de obelisco que mide unos 5,90 metros de altura, con curiosas tallas serpentiformes en su rugosa superficie. Hay versiones que dan a esta mole la forma de puma. Los lugareños, empero, aseguran que éste es el "templo de la fertilidad", y han comparado la piedra en mención con un enorme "falo" que apunta al cielo. Los cronistas españoles cuentan que los sacerdotes venían aquí en fechas especiales para realizar rituales del agua y la fertilidad, derramando la sagrada chicha de jora por los surcos y canalillos de la roca, a manera de ofrenda a las divinidades. 
El origen de estas moles talladas por la mano del hombre es incierto. Algunos le atribuyen una antigüedad preinca, mientras que otros le han dado connotaciones cósmicas y astronómicas e, incluso, como una de las entradas secretas de las famosas "chinkanas", esos túneles que se pierden en la profundidad de la tierra, a los que se señala como el escondrijo de los tesoros de los incas.

\section{El servinacuy, matrimonio "de a mentiras"}

"Todo connubio entre campesinos se formalizaba después de un tiempo más o menos largo de cohabitación prematrimonial llamado tincunacuspa en el sur y pantanaco en el norte. En él se buscaba que los futuros contrayentes pudieran descubrir la compatibilidad o incompatibilidad de sus sicologías, bajo la estricta vigilancia de sus padres; por cuanto el pantanaco podía cumplirse tanto en casa del futuro esposo como en el de la futura compañera."

\section{Waldemar Espinoza Soriano. (26)}

Los incas no se quedaron atrás en cuanto a los placeres sexuales y la actividad reproductiva. Y no sólo esto, sino que con su sentido práctico y previsor supieron normar la natalidad en el Tahuantinsuyo (en esto se adelantaron a su época) (16) con políticas de estado que lograron equilibrar el aumento de una gran población. Al igual que sus predecesores, pero con una organización social perfeccionada, los incas valoraron mucho el matrimonio (18), al que le dieron un "status legal" a la altura de la urdimbre política, económica y social del imperio del Tahuantinsuyo (16). Más que la simple unión hombre-mujer, el casamiento inca tenía un sentido bastante diferente al que conocemos nosotros. Lo que sí tenían en común con nuestras bodas actuales es que, supuestamente, eran un "contrato" para unir a dos personas, hombre y mujer, con fines de formar un hogar y tener descendencia. Tanto ayer como hoy, los matrimonios concertaban alianzas y relaciones de parentesco. $Y$ todo esto enmarcado 
en una especie de ley no escrita que conformaban las reglas que rigen sobre la selección de los cónyuges, ya que ninguna sociedad permite una selección totalmente libre.

Cuando los Incas empezaron a anexionarse vastos territorios para formar el Tahuantinsuyo (16), los pueblos conquistados comenzaron a experimentar grandes cambios en sus costumbres y tradiciones locales a pesar la tolerancia que los reyes Incas solían brindar después de cada conquista. Y esto, a pesar de que la iconografía y la cerámica cusqueña no alcanzó el brillo interpretativo ni la expresividad artística de los pueblos preincas. Con los Incas aparece en el Perú un nuevo orden geopolítico con el que se ejercía el control total sobre la población. Este fue el caso del "servinacuy". "En este sentido -cuenta Christian Vitry () -, podemos decir que para los Incas, el matrimonio era una cuestión de estado, un acto administrativo y no necesariamente religioso. El principal interés por el casamiento radicaba en el hecho que la pareja recién formada recibía del estado su parcela de tierra, granos y todos los elementos necesarios para empezar a producir y tributar. Por otra parte, el incremento de personas fue estratégicamente importante para un estado en franca expansión como el de los Incas." (18) 


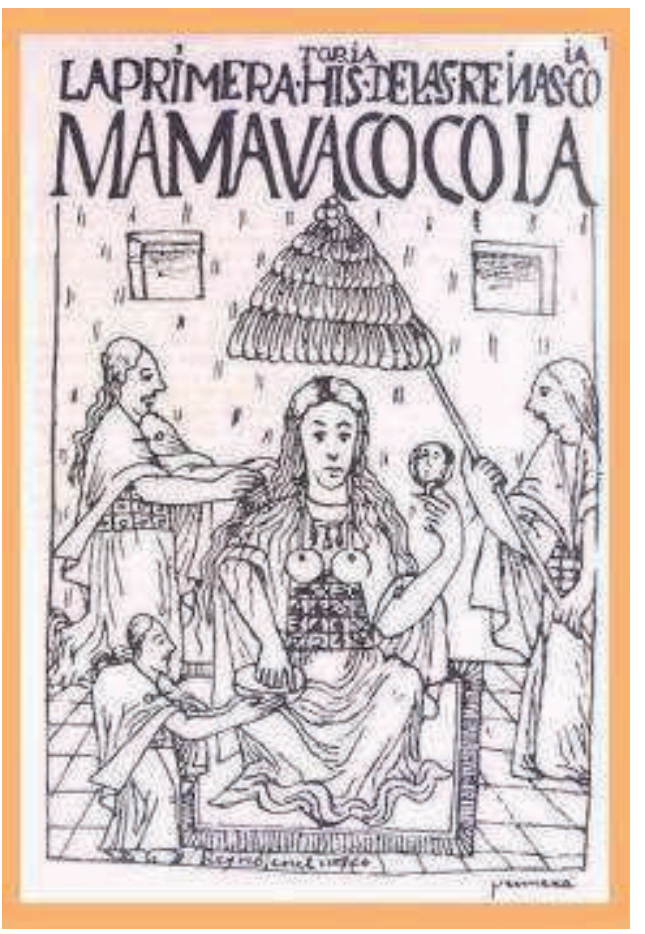

Figura 13. "La primera historia de las reinas coyas", es el título de esta ilustración del cronista mestizo Guamal Poma de Ayala (1615) "Mama Guaco Coya, marca el comienzo de las reinas coyas esposas de los inkas, dicen que ella era hija del Sol y la Luna, con la autorización de su padre Inti se casó con su primer hijo Mango Capac Ynga." (18) Así es como el cronista resalta la importancia que el matrimonio tuvo entre los incas. Ilustración del portal del "Museo de Antropología de Salta" (Argentina).

El casamiento, entonces, era considerado como el estado normal a que llegaba un hombre adulto. Esto incluía a los sacerdotes. Los únicos que no se casaban eran los ascetas o ermitaños y los prostitutos de los templos. Dentro de las panacas -familias nobles o dinastías - reales, el Inca de turno tenía en la "colla" a su esposa principal, pero se permitían tener en su palacio un número indeterminado de concubinas; estas mujeres también vivían en las residencias de los nobles, funcionarios, jefes militares y otras autoridades. Era una suerte de "haren" cuyo número dependía del estatus social y jerarquía política y económica del esposo, toda vez que en el hombre de la calle, el acceso a esta "promiscuidad" oficial era más difícil y la mayoría tenía que arreglárselas con una sola esposa. El habitante del Tahuantinsuyo (16) era, pues, monógamo, salvo en las esferas del poder. (18 - 19)

Los matrimonios se realizaban en ceremonias públicas y no estaban exentas de solemnidad. En la plaza del pueblo o ciudad, vale decir, en la "llacta", el novio recibía a la novia de manos del monarca o de algún representante suyo. Ésta era la única forma de que la unión fuera legal. "El estado establecía fechas específicas cada 1 ó 2 
años -cuenta Vitry -. Acudían todos a la plaza principal de cada capital de provincia (...) donde formaban filas separadas acorde al sexo, rango y parentesco, con el objetivo de ser emparejados y casados por el Inca" (18). Las parejas solían casarse muy jóvenes, entre los 15 ó 20 años -un poco menos para las mujeres-, y el hecho de casarse estaba asociado a la mayoría de edad para formar un hogar, producir y tributar.

"Las mujeres de los monarcas o los "kuracas" -prosigue Vitry - salían de los "acllahuasis" (casas de las escogidas) y se procuraban los casamientos entre parientes. Las acllas o escogidas para ser distribuidas por los funcionarios Incas como esposas o concubinas tenían entre 13 y 15 años de edad. Las demás mujeres que quedaban sin casarse las llamaban guasipas, las que quedaban a cargo de los kuracas, quienes las hacían trabajar y disponían de su casamiento sin que el Inca entendiese en el tema, salvo el caso que quisiese para sí o algún dirigente jerarquizado alguna de ellas. El resto las casaba con los hatún runas o tributarios, quienes debían hacer un presente al padre de la novia y al Kuraca (Santillán, 1950). Los miembros comunes del estado no recibían las esposas de los acllahuasis." (18)

\section{Pampayrunas: prostitutas del incario}

"Pampayruna era en el Incario "mujer pública", según el Inca Garcilaso de la Vega. Sorprende la afirmación del mestizo cronista dado que todos conocemos que su tendencia es más bien a idealizar el Incario, a verlo en la forma en que seguramente lo entendían los aristócratas orejones imperiales cuzqueños, de quienes tenía sangre, a través de su madre Isabel Chimpu Ocllo. Pero ¿qué es una prostituta? La mejor definición sigue siendo la de Justiniano, el de los códigos romano-bizantinos: "mujer que se entrega por dinero y no por placer". 
"Por esta sencilla razón, denunciar que hubo prostitución en el Incario rompe con todos los esquemas garcilacistas; lo que es peor, deshace todas las demás informaciones en torno a la sociedad incaica. Resulta así imprescindible una revisión del caso. Además, la discutida aseveración garcilacista hundiría todos los esquemas vigentes en torno a la evolución universal de las sociedades, puesto que el Antiguo Perú no pasó del Calcolítico (cobre y piedra). Período que aunque brillantemente cumplido, no llegaba aun a los niveles económicos de la evolución que son base para el surgimiento de ciertas instituciones y costumbres, la prostitución entre ellas."

Juan José Vega (33)

Cuentan los cronistas de la Conquista que los reyes incas y aún la nobleza cusqueña eran los únicos que podían permitirse el "lujo" de contar con verdaderos "harenes", muy al estilo oriental. Pero éstas eran mujeres muy especiales. Los Incas tuvieron una vida sexual tan activa como la de sus antecesores, aunque ellos le pusieron lo suyo. Con sus brillantes conquistas, los reyes cusqueños avasallaron las viejas culturas llevando otras costumbres y formas de vida que éstos tuvieron que adoptar. Una de ellas era la presencia de mujeres públicas que, como ahora y como siempre, prestaban sus servicios amorosos...

La prostitución fue una actividad muy difundida en el Tahuantinsuyo. Las mujeres que practicaban este oficio recibían el nombre de "pampayrunas" (Nota 10) y eran toleradas por el Inca, como indica Christian Vitry, (21) quien, citando a los "Comentarios Reales de los Incas" relata que "Los hombres las trataban con grandísimo menosprecio. Las mujeres no hablaban con ellas, so pena de haber el mismo nombre y ser trasquiladas en público, y dadas por infames, y ser repudiadas de los maridos si eran casadas. No las llamaban por su nombre propio sino pampayruna, que es ramera". (Garcilaso 1968, IV, XIC)". 
Hay autores que hablan de la imposición con que los Incas sometían a estas mujeres para que ejercieran, de grado o fuerza, la prostitución para evitar, por ejemplo, el adulterio o las violaciones. Así, el historiador Waldemar Espinoza, nos dice que... "no la ejercían mujeres que por su propia voluntad e impelidas por la necesidad se hubiesen metido a ejercitarla" (26), pero que los propios gobernantes del Tahuantinsuyo mantenían una actitud esclavista sobre estas mujeres. "En efecto prosigue Espinoza - con la finalidad de que los solteros no trastornaran el orden social estuprando a muchachas o deseando a esposas ajenas, Pachacutec dio varias resoluciones regimentando la prostitución:

$1^{0}$ Que los prostibularios estuviesen edificados fuera de las llactas (ciudades incaicas).

$2^{\circ}$ Que allí se ganaran la vida únicamente mujeres prisioneras, capturadas en las guerras.

$3^{\circ}$ Que percibiesen un pago dado por cada cliente que las solicitara.

$4^{\circ}$ Que en caso de quedar embarazadas y dar a luz, se les quitará a los niños para alojarlos en casas especiales a cargo de mujeres honestas que carecieran de hijos.

$5^{\circ}$ Considerar a tales chiquillos, hijos de todos los hombres que habían cohabitado con sus madres; y una vez mayores, se les encaminará como trabajadores a los cocales, al lado de los "pinas".

$6^{\circ}$ Debían vivir en chozas individuales, impedidas de entrar en las llactas y ayllus. Precisamente por parar en el campo se les decía "pamopayrunas", o sea, mujeres públicas, dispuestas a recibir a cuantos querían acercárseles, por lo que también se les decía "mitahuarmis": mujeres de turno." (26)

Así de penosa era la vida de estas pobres mujeres. Por desgracia, no se sabe qué era lo que pasaba con ellas al envejecer, cuando la edad les imposibilitaba seguir en el oficio impuesto por el Estado. Quién sabe si más de una debió extrañar en cierto modo la época en que sus pueblos eran más libres y ellas no tenían que llevar a 
cuestas tan extraño "oficio" impuesto, al cual no podían escapar so pena de la muerte o el escarnio público. (Nota 12)

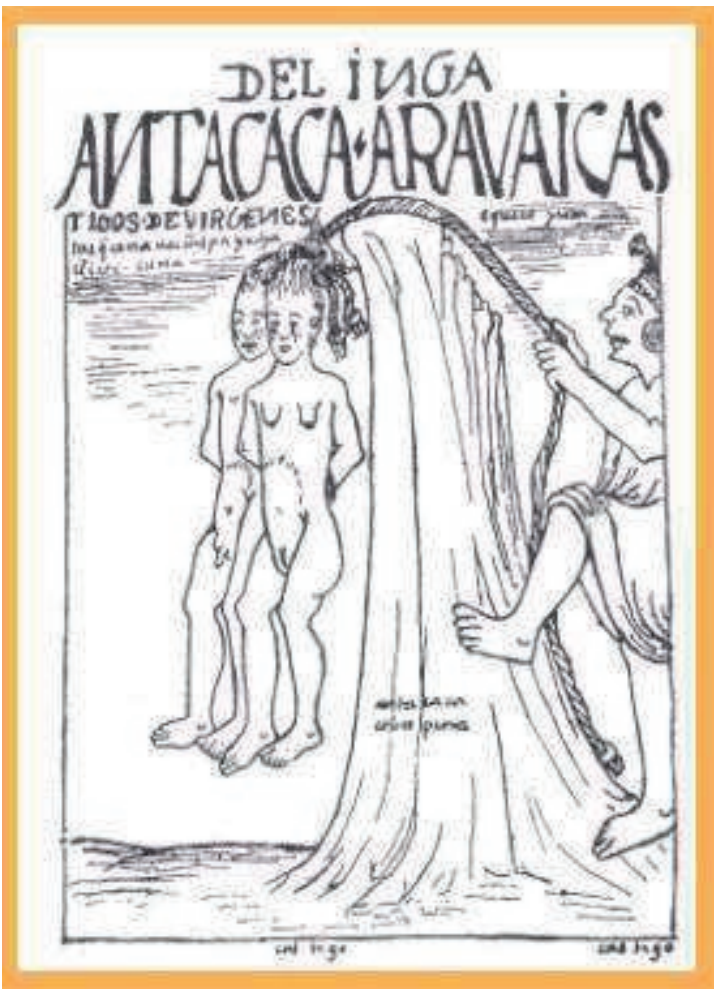

Figura 14. "Virgen del Sol o aklla colgada de los cabellos en un araway junto a su amante, por transgredir las normas del imperio Inka." Triste era el destino de muchas "mujeres públicas" en el incario; la menor falta no perdonaba a nadie, ni siquiera a estas pobres mujeres, verdaderas vestales del imperio inca, como se puede observar en este crudo dibujo del cronista Guamán Poma de Ayala (1615). Ilustración del portal del "Museo de Antropología de Salta" (Argentina). (21)

\subsection{Sodomía ritual}

Pedro Cieza de León, en su libro "La Crónica del Perú" (27), revela asimismo la existencia de otras formas de desviaciones sexuales durante el incario. La promiscuidad sexual era tal que se podían encontrar prostíbulos incluso en lugares donde era poco común ver un acto de sodomía. A la par, Garcilaso en sus "Comentarios Reales" admite que en ciertas etnias se practicaba la sodomía religiosa o ritual. (Nota 11): "Hubo sodomitas en algunas provincias, aunque no muy al descubierto, sino algunos particulares y en secreto". (Garcilaso 1968, I, XIV) (Nota 11). Esto lo confirma Cieza de León, quién detalla: "Verdad es que generalmente entre los serranos y yungas ha el demonio este vicio debajo de especie de santidad, y es que cada templo o adoratorio principal tiene un hombre o dos o más, según es el 
ídolo, los cuales andan vestidos como mujeres desde el tiempo que eran niños, y hablaban como tales, y en su manera, traje y todo lo demás remedaban a las mujeres. Como éstos, casi como por vía de santidad y religión, tienen las fiestas y días principales su ayuntamiento carnal y torpe, especialmente los señores y principales.

Esto sé porque he castigado a dos: $[\ldots] \ldots$ a los cuales hablándoles yo sobre esta maldad que cometían, y agravándoles la fealdad del pecado, me respondieron que ellos no tenían culpa, porque desde el tiempo de su niñez los habían puesto allí sus caciques para usar con ellos este maldito y nefando vicio y para ser sacerdotes y guarda de los templos de sus ídolos." (Cieza 1945, LXIV).

En torno a esto, Vitry (21) no se cansa de advertir que... "Los documentos de los cronistas siempre deben ser tomados con reserva, debido a que están escritos bajo un halo moralizante e idealista, tanto a favor de los inkas como de la corona o la iglesia. Por ejemplo, Antonio de Herrera y Tordesillas, en su libro "Historia general de los hechos de los castellanos en las islas, y Tierra-Firme del mar Océano" de 1601-15, en su catálogo de las penas judiciales inkaicas, no comenta nada respecto a que las prostitutas fuesen castigadas. Menciona en cambio algo que resulta curioso, el castigo al lenocinio, que en aymara recibe el nombre de sakeri, al respecto el autor comenta que "Al alcahuete le daban tormento públicamente, habiendo junta de gente, y si perseveraba en el vicio, le mataban" (Herrera 1945, V, IV, III).

Han transcurrido casi cinco siglos desde la llegada de las huestes de Pizarro y Almagro al corazón del imperio Inka, el golpe fue letal y un nuevo orden se impuso por la fuerza. Hoy, contamos sólo con jirones de la rica historia precolombina, reflejada, como en este caso, a través de algunos documentos, o bien, en las inertes ruinas arqueológicas, silentes testigos de una efervescente sociedad que dominó gran parte del mundo andino." 


\section{8. ¿Quién les enseñó este arte a los aborígenes peruanos? (habla Kauffmann Doig)}

Las creencias de estos pueblos no sólo consideraban la unión carnal entre hombres y mujeres como una función mágica, sino que también atribuían a la tierra una función similar, la fertilidad de la tierra fecundada por el cielo -la lluvia-, que no hacía más que corroborar la continuidad del ciclo de la vida en todos los reinos de la naturaleza. Como parte de este contexto, lo representado en los llamados huacos eróticos, como ya mencionamos arriba y veremos a continuación, es algo que supera a la imaginación alucinada de los autores del "Kamasutra", vale decir, la creatividad de unos alfareros que convirtieron el barro en un arte de contorsionistas.

Las posturas de los personajes de la terracota moche, las parejas de amantes, hombres y mujeres que se unen carnalmente en las perpetuas, inmóviles, pero vividas recreaciones artísticas de la cerámica erótica peruana, nos presentan un universo de infinitas expresiones coitales o posturas dignas de un yogui oriental, donde personajes de ambos sexos -y raramente las parejas unisexuales - son mostradas con tal realismo que parecen exhalar el hálito de una experiencia vital. Nadie ha podido describir tan vividamente las costumbres amorosas de los antiguos peruanos como lo hicieron los anónimos ceramistas de los tan certeramente conocidos como huacos eróticos.

Como describe el doctor Fernández (13), estas representaciones de la vida amorosa o coital las encontramos en todo el Perú; pero es en la región costera del norte y central peruana donde este arte alcanzó su mayor perfección. Se presume, como ya indicamos arriba, que este arte fue pasando de pueblo en pueblo, cada cual perfeccionó las técnicas de fabricación y diseño de estos ceramios. Los mochicas, finalmente, fueron el cenit de este arte. 
En su gran obra, "Arqueología Peruana" (22) Federico Kauffmann Doig intenta llegar al fondo del enigma de los huacos retrato mochica, y en particular, de la cerámica erótica... "No faltan, finalmente, escenas de la vida sexual y su ritualismo -que han hecho pensar en la existencia de costumbres deprabadas (sic)*-, tema sobre el que ha discurrido pasajeramente Gutiérrez de Quintanilla, Posnansky y, posteriormente, J. C. Muelle, el malogrado escritor Kinsey y Rafael Larco."

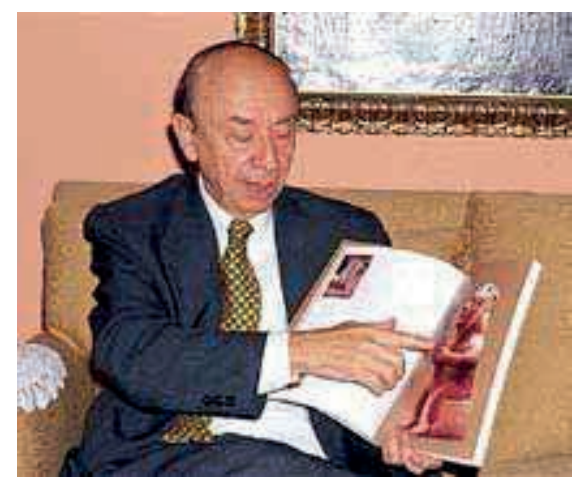

Figura 15. El arqueólogo Federico Kauffmann Doig mostrando las ilustraciones de uno de sus libros. Foto del Museo Larco publicada por la revista "Rumbos del Perú" \# 28

No sin manifestar su sorpresa ante la gama de formas y figuras humanas y expresiones de todo calibre, y el "atrevimiento" de los alfareros moche, que no dejaron nada al azar y todo lo retrataron en sus huacos, el autor, no encuentra a veces palabras -o si las encuentra... las disimula, trata de quitarles "fuerza" acudiendo a términos griegos o latinos - para mencionar algunos de los "órganos sexuales" humanos representados en la cerámica mochica, pero lo hace no sin ciertas reservas... "Resulta lógico que el artista Mochica, empeñado en plasmar en su cerámica todo lo que le circundaba, como lo demuestran las tan variadas representaciones, no pasara por alto la vida sexual y su ritual. Empero en lo que se refiere a las prácticas sodomitas, cuya presencia en el antiguo Perú es innegable, los Mochicas parecen no haber gustado de representarlos. En contradicción con la versión popular tan difundida, no se presentan casos de homosexualidad en las representaciones relativas a la vida sexual, como puede dirivarse (sic)* a través de un análisis de la importante colección de cerámicas de este tipo existente en el Museo Nacional de Antropología y Arqueología. 
Según los informes verbales del Sub-Director de dicho museo, sólo una pieza (en el depósito), reproduce un ayuntamiento sodomita**, y hasta esta excepción se presenta discutible ante un análisis detenido por cuanto no se percibe en forma clara los detalles. Larco parece poseer algunos ejemplares, pero pocos, tal vez menos del 1 ó 2\% del total de huacos de representaciones sexuales. Entre las representaciones sexuales aparecen pues, por lo general, casos de cohabitación entre hembra y varón, solo que la mayor de las veces éste es per os***. También se ve, con relativa frecuencia, casos en que la madre sostiene a su infante mientas cohabita al modo señalado, y se ha dicho que ello obedece a un preventivo de embarazo; para que la criatura pudiera lactar mayor tiempo. No pocos ceramios muestran otras variantes sexuales; en todos los casos los que intervienen son parejas heterosexuales, primando siempre las de tipo ana. Son frecuentes los casos de ayuntamiento de animales; y los hay en los que aparece un varón fertilizando vegetales, de evidente raíz ritual. Otros huacos muestran cabezas de lechuza coronadas por un phalo***, y hay casos camuflados, de personas que constituyen phalos**** disimulados que se descubren sólo observando la vasija en cierta posición. Los sujetos provistos de un pene erecto de tamaño descomunal han contribuido, sobre todo, a que se haya concebido la existencia de un culto fálico como se supone lo hubo en otras culturas. Debido a que algunas de estas representaciones de phalos**** desproporcionados forman parte de un cantarillo cuyo orificio está precisamente en la parte anterior del pene, por donde se vierte el líquido contenido en la vasija, se deduce que su uso pudo estar vinculado íntimamente a prácticas vinculadas con la fertilidad. El lugar por donde se llena el líquido es amplio pero se quizo (sic)* obligar a beber por el pene mismo, ya que los diversos agujeros hechos en la entrada donde se llena el líquido está provisto de orificios que lo impiden hacer por este sitio. Cosa semejante sucede con las vasijas expandidas de doble fondo de formas femeninas: en el fondo inferior penetra el líquido vertido, pero éste al beberse escurre por el orificio que corresponde a la "roca" o vajina. (sic)* No es improbable que estas "pacchas" sexuales -usadas al parecer entre los vivos y no para irrigar huacas - se usaron como instrumentos jocosos y de 
diversión durante las estruendosas fiestas y orgías simbólicas de la fecundidad, para beber de ellas simplemente. Pero pudieron, tal vez, ser usados especialmente en ritos de fecundidad humana, para atraer por la magia el embarazo."

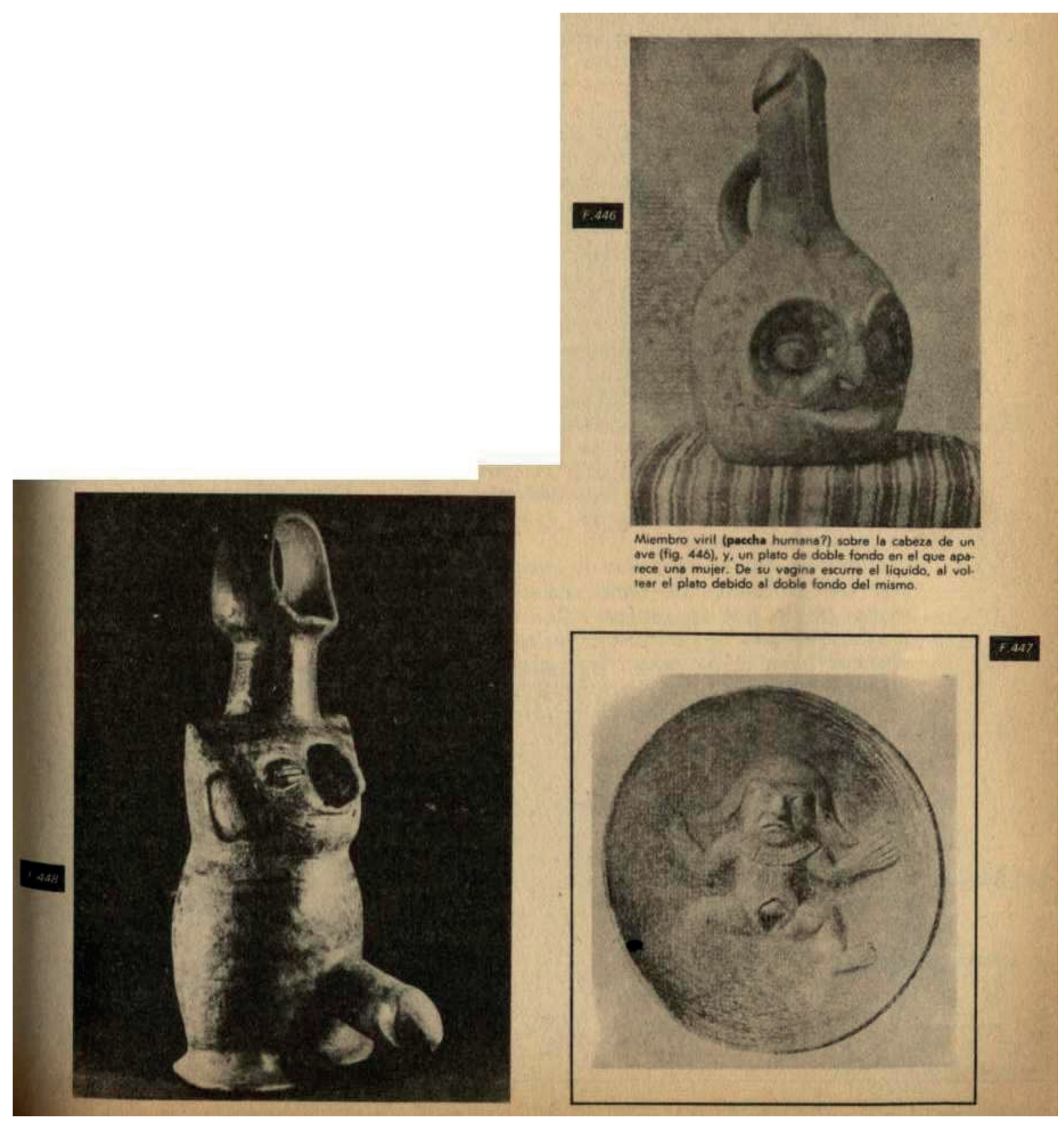

Figura 16. Las curiosas ilustraciones mencionadas arriba por Kauffmann Doig. A la izquierda, en una leyenda de foto que no aparece en la ilustración por estar en otra página, el autor hace esta descripción: "En épocas anteriores a la Mochica, en Vicús, 
de donde procede la pieza 448, encontramos a veces a seres de narices-picos con el miembro viril remarcado. En otras tradiciones culturales peruanas no sólo son casi nulas las representaciones, hasta se diría que intencionalmente se les evita, como, p. ej, en los cuchimilcos de Chancay."; arriba, a la derecha: "Miembro viril (paccha humana?) sobre la cabeza de un ave (fig. 446), y, un plato de doble fondo en el que aparece una mujer. De su vagina escurre el líquido." De esta última ilustración, el autor omite la nomenclatura de la misma, la fig. 447.

"Existen, finalmente, casos de acoplamiento por vía anal en animales aunque, repetimos, siempre entre sexos diferentes. En el estudio de la cerámica sexual Mochica es necesario tener presente, que no se conocen datos provenientes de hallazgos in situ, de las tumbas, lo que hacen suponer que existen falsificaciones. Los hay, seguramente, algunos, al lado de las burdas que no se toman en cuenta.

Digamos, finalmente, que la proporción de los huacos de tema sexual es menor de la que se supone. De entre muchos millares de cerámicas uno o dos expresa asuntos de sexo. En general, en el antiguo Perú, las figuras de tema sexual no sólo son escasas; se insiste más bien en representaciones de sujetos asexuales o a los que no se les hace destacar el sexo."

El tema le pareció tan interesante (y también tan picante) al arqueólogo Kauffmann Doig, que no ha escatimado espacio en su libro para referirse al erotismo moche con algunas alusiones a otras culturas (caso Vicús), no sin ocultar cierto sonrojo por tener que citarlos como parte del pasado peruano, y termina denunciando, como el doctor Fernández (13), la indiferencia académica existente hacia este tema... "Nos hemos permitido extender más de la cuenta sobre el tema, debido a que este es generalmente soslayado, por considerársele azaroso, haciéndose a su alrededor sepulcral silencio." 


\section{NOTAS DEL PÁRRAFO}

* (sic), suponemos que las faltas ortográficas encontradas en el texto consultado son de edición, por no decir que son las del autor, o de impresión; aunque, por cierto, no desmerece la calidad de la obra ni del contenido en sí.

Volver al párrafo

** Al parecer, se trata del mismo caso descrito por el doctor Enrique Fernández, quien comenta que Gebhard encontró "...sólo un caso de relación sexual de una mujer con un ave, que por el tema recuerda a Leda y el cisne que, como se sabe, fue tratado por Leonardo y otros artistas. Otro huaco que está en el Museo de Arte de Chicago representa a una mujer con un perro. Este caso Larco Hoyle lo discute y para él representa a una mujer atacada y derribada por el perro." (ver: subcapítulo 3.3.4. La humanidad de la arcilla II).

Volver al párrafo

*** El párrafo original del autor, Federico Kauffmann Doigque, dice así: "Entre las representaciones sexuales aparecen pues, por lo general, casos de cohabitación entre hembra y varón, sólo que la mayor de las veces éste es per os." Empero no encontramos el significado de "per os." (22)

Volver al párrafo

**** En algunas partes de este subcapítulo que el autor dedica a la cerámica erótica moche, escribe las acepciones griegas "phalo" y "phalos"; sin embargo, en otros puntos menciona las mismas palabras pero en terminología castiza: "falo" y "falos"; ¿adrede? ignoramos el motivo de esta aparente ambigüedad lingüística. 


\section{Epílogo}

Mucho queda aún por decir de este universo increíble que es el Perú precolombino, donde cualquier cosa es posible, como sucede en las mitologías griegas... allá, en las tierras olímpicas, así como los hombres y las mujeres se relacionan, odian y aman, se casan y procrean, los dioses y diosas del Olimpo seducen a los/as incautos/as mortales y tienen amores prohibidos con ellos/as y, como los terrenales hijos de Adán y Eva, también tienen hijos, éstos acaban convirtiéndose en héroes o semidioses, y conviven hasta que el humor hepático de alguno de ellos los haga cambiar de parecer y se vayan con la otra o el otro. Pero, ojo, esto pero no todo... al parecer los antiguos peruanos tenían un concepto muy distinto al del mundo griego o europeo; al menos esto se trasluce en la fogosidad de sus representaciones eróticas, las mismas que, seguro, aturdirían a los mismísimos dioses. Y eso mismo, debió suceder entre los peruanos de antes de la llegada de los conquistadores, que vinieron en sus "extrañas balsas" con todo su stock de extirpadores de idolatrías y arrasadores de templos indianos; aún así, nadie puede negar que cuando arribaron a costas americanas, los forasteros quedaron alucinados: se tropezaron con un mundo de costumbres y hábitos sociales que en nada tenían que envidiar a los del viejo continente.

Por suerte se les pasó el dato... de los huacos -que de puro iconoclastas habrían acabado con ellos - ; no los vieron ni cuadrados ni redondos.

Gracias a ello, la iconografía del antiguo Perú nos muestra el recorrido del arte como representación realista de la vida cotidiana, a la vez que nos lleva a un mundo donde magia y ritual se confunden; magia y ritual que fue el común denominador de un pueblo que temía y respetaba a la naturaleza, y consideraba el hecho de estar vivos como un regalo de los dioses. Las representaciones eróticas encontradas en su cerámica no son, pues, pornografía como muchos pretenden atribuir, es simplemente 
el retrato vivido de algo tan natural como la existencia misma, por lo que en su cosmovisión consideraban a la fertilidad como algo sagrado, que algunas culturas del ande representaban incluso en sus templos cuyas singularidades -como por ejemplo, los falos erguidos de los que ya hemos hablado en el capítulo 4 - han hecho pensar a los arqueólogos que todo esto parece responder a simbolismos, que sino a la necesidad de representar el quehacer sexual, o a rituales de la fertilidad, e incluso que tales ceramios pretenden mostrar acontecimientos o momentos de clímax en la vida de las personas retratadas, cuales fotografías de terracota, o eran el relato vivido, para la posteridad, de cómo eran sus costumbres ancestrales o contaban sus leyendas, que también personificaban en la forma de un huaco retrato o erótico con el mayor realismo.

\subsection{Extirpadores de idolatrías y otros diablos... vade retro}

Y aquí pensamos en lo que hubiera pasado si este maravilloso arte precolombino no llega a nosotros... seguramente estaríamos tan lejos de conocer este mundo sorprendente ¿y si los extirpadores de idolatrías los hubieran encontrado... en manos de algún pobre plebeyo? ¿Qué hubiera pasado? ¿Cacería de brujas? No, eso no pasó, que si no fue por esto fue por otras cosas que no entran en esta historia; entonces, que sepamos, hasta ahora nadie ha dicho nada... aunque ahora muchos quieren callarse. Y seguro que no pasó, pues, de lo contrario, al bueno de Torquemada se le hubiera quemado la sotana.

Pero parece que él tampoco se enteró y los huacos los tenemos aquí, y también todo el arte que nos habla de ese mundo perdido llamado Perú precolombino.

Aunque nos consta que hubo algunos en la época del Virreinato que sabían de los huacos, pero su astucia les hizo callar... "más sabe el diablo por viejo que por diablo..." 
Los viejos moches se guardaron el secreto hasta que los arqueólogos y los huaqueros hicieron su trabajo.

Sí, pues, en el viejo Perú -como en la antigua Grecia o en las mitologías nórdicas "hasta los dioses coitean" -parece que don Artidoro Cáceres no estaba tan descaminado - .

Yo tampoco lo creo (permitidme la licencia).

No es pornografía; es arqueología... o la más depurada expresión plástica del arte en el antiguo Perú y tal vez del mundo.

No es pornografía, pero ya hay sinvergüenzas que irresponsablemente han tratado y tratan de utilizarlos para vender o satisfacer su morbo, colocándolos incluso en páginas Web donde magnifican y resaltan exageradamente los bajos instintos que estos individuos, sujetos de rastrera moral, representan.

Los huacos retratos y los huacos eróticos -ambos, expresión exquisita de los alfareros del norte peruano - pertenecen al patrimonio cultural de la humanidad; son parte de aquel mundo desaparecido; ellos, las culturas peruanas, que desde la bruma del ayer nos piden les escuchemos.

La arqueología (y los huaqueros, para mala o buena suerte) los encontraron.

La arqueología no busca ruinas, busca gente... aunque de paso encuentra alguna que otra ruina, los pueblos donde vivió la gente, las casas donde nacieron sus hijos, los talleres de los anónimos artistas, los lugares donde lloraron a sus muertos, y allí quedó la historia, intensamente humana. 
El arte erótico mochica -como el de otras culturas peruanas y americanas, y aún de Europa, Asia o África, que en todas partes se cuecen habas o pallares - se desarrolló dentro un espacio tiempo como expresión de la creatividad humana, bajo el influjo de una coyuntura social, política, económica y religiosa muy complejas que nos dejó la expresividad plástica de su cotidianeidad. La cerámica erótica, al igual que los huacos retratos, eran una forma de comunicación intensamente humana, de emociones y gestos propios de aquellas gentes. Todo esto; más nunca "pecado nefando" -al decir de un cronista de la Conquista española-, jamás morbo, muchísimo menos ese "sadomasoquismo" propio de nuestra "modernidad". Todo aquí tiene una lógica; el arte de los huacos retratos o eróticos tuvo una finalidad práctica o religiosa: rito, magia, sensaciones y representaciones de vivencias o estados de ánimo, alegría, tristeza, miedo, angustia, enfermedad, castigo, premio, dolor, placer. Todas obras de arte fueron creadas precisamente para eso: para representar la humanidad de los hombres y mujeres, niños y ancianos, de los valles donde vivieron $\mathrm{y}$, como tal, y para que perduraran para siempre, pasaron a formar parte de ajuares funerarios, depositados con delicadeza en las tumbas de los difuntos por sus seres queridos; los huacos terminaron acompañando los yertos despojos humanos en su viaje al más allá. Aquí, entonces, no hay nada de eso que algunos malintencionadamente llaman "pornografía". Esta es una palabreja que simplemente no encaja en el antiguo Perú y que no la inventaron ellos, los antiguos peruanos, sino la estupidez de nuestra "moderna civilización" occidental. Esta "modernidad" donde el consumismo y el capitalismo salvajes empobrecen y hambrean a millones a cambio de la riqueza de unos pocos; que cosa peor que ese neoliberalismo inmoral y criminal, tanto peor que la pretendida "indecencia" de ese mágico erotismo del arte precolombino.

Esa sarta de tabúes que hemos inventados en nuestra supina ignorancia no estaban en los esquemas mentales de aquellas gentes; ellos tuvieron su propia forma de ver el mundo antiguo como nosotros la tenemos de nuestra locura "moderna"; ellos, 
entonces, fueron como fueron, y porque fueron así no les podemos dar la espalda; no podemos condenar el pasado sólo porque sus protagonistas pensaron diferente a nosotros, no podemos condenar el pasado sólo porque nosotros pensamos distinto a ellos; no podemos condenar el pasado sólo porque alguien de ese entonces fue diferente a nosotros... como nosotros lo somos de ese alguien anónimo que desde otros tiempos supo expresarse mejor que nosotros. Ellos, nuestros ancestros, estuvieron aquí y tienen una enseñanza; rechazarlos significa rechazar una parte de nosotros.

La arqueología encontró a la gente de moche, como a la de allá, como a la de acullá; apareció la gente de los siglos perdidos, sino sus sombras, sus creaciones artísticas, los viejos huacos que quieren hablarnos; allí están, hombres y dioses de la arcilla, viviendo la eternidad de sus gestos, de sus gritos y cantos mudos, de sus miradas; la gente de la tierra vive en sus sueños de terracota; son los hombres y las mujeres de los valles, de los ríos, de las leyendas y de los sueños de bruma.

Los Mochicas no tenían una escritura como la concebimos, pero eran eximios dibujantes y mejores alfareros. Y con ellos, otros pueblos del antiguo Perú pusieron su cuota de ingenio creativo. Los Paracas crearon los tejidos más perfectos y coloridos de la América prehispánica; los pobladores de Nasca diseñaron la cerámica más bella por sus colores; los hombres de Chavín tallaban la piedra con singular maestría; los artesanos chimú nos legaron joyas de técnica inigualable... Gracias a eso sabemos más de ellos que lo que nos hubiera contado una biblioteca entera.

\section{0. ¿Sabía usted qué...?}

...según afirmaciones del arqueólogo Kauffmann Doig, de los aproximadamente cinco mil ceramios ---escultóricos y de otra índole - encontrados hasta la fecha en el Perú, en su mayor parte procedentes de culturas del norte peruano -aunque 
pensamos que tal cifra es muy mezquina con la realidad -, se estima que al menos la mitad corresponde al género erótico?

...un gran porcentaje de los ceramios eróticos exhibidos en museos del Perú y el mundo no fueron precisamente encontrados por arqueólogos, sino por "huaqueros", ladrones de tumbas, financiados por mafias de traficantes de piezas arqueológicas. Los "huaqueros" fueron quienes hicieron llegar a Rafael Larco gran parte de su vasta colección de huacos Mochica, Vicús, Virú, Salinar, Cupisnique y otras culturas norteñas que hoy asombra al mundo?

...según Kauffmann Doig, "los incas no permitieron en su cerámica el tema sexual. Pero sabemos bastante de ella a través de la etnohistoria y las fuentes etnográficas. El servinakuy, que ahora parece mundial, es una gran enseñanza del Perú antiguo"?

...los menhires fálicos de Monsaraz (Portugal), tal uno de los conjuntos megalíticos más viejos de la península ibérica, podrían tener una antigüedad de hasta 4.400 años antes de Cristo? (34)

...en el "Museo Nacional de Arqueología, Antropología e Historia del Perú", (MNAAHP) de Pueblo Libre (Lima), cientos de huacos eróticos permanecieron escondidos durante décadas en los depósitos de este enorme edificio; en marzo del 2004 fueron sacados "a la luz", tras casi medio siglo de "ostracismo", para una exposición temporal alusiva al tema sexual en el antiguo Perú, pero, una vez concluido el evento fueron de nuevo guardados sin mayores explicaciones?

...es tal en "ninguneo" que existe al respecto en el referido museo que hace poco, cuando quisimos inquirir sobre el paradero de dichos ceramios, el personal del museo se encogió de hombros, y una funcionaria sugirió (¿?) a VA dirigirse... al 
"Museo Larco", ubicado cerca de allí, institución que, por cierto, tiene su propia colección de cerámica erótica en una exposición permanente? (35)

...algunos de los huacos eróticos del MNAAHP fueron donados a esta institución por el estudioso Larco Hoyle y otros llegaron por distintos medios; estas piezas fueron estudiados por Julio C. Tello -ver: "La antigüedad de la sífilis en el Perú" - Una tesis de Julio C. Tello (30) - y otros investigadores, pese a ello han permanecido injustificadamente en la oscuridad salvo raras excepciones, como la mencionada en estas líneas?

...el poder entre los mochicas tuvo su base en los sacerdotes y su manipulación de las ideas religiosas?

...el panteón mochica se componía de cuatro divinidades?

...quien esto escribe recuerda que hace unos 35 años, los textos escolares de Historia del Perú enseñaban que los antiguos peruanos desconocían los sacrificios humanos con fines rituales, es más, se decía que los Mochica sólo sacrificaban animales, al igual que los incas?

\section{Para saber más}

(Nota: A la derecha de los hipervínculos se ha insertado la fecha de última apertura de la página Web citada)

"Las capullanas" (Artículo del historiador peruano Juan José Vega) http:/ / lacapullana.tripod.com.pe/lascapullanas.htm 12/5/04 
"Les megalithes" (en francés)

http:/ / www.ot-trinite-sur-mer.fr/trinit/doc/megalith/doc/megalit.htm 20/5/04

"Apuntes sobre la erótica AEgyptiaca" - Amigos de la Egiptología.

http:/ / www.egiptologia.com/mujer/erotica/erotica.htm 19/4/05

"El sexo antes de Colón" (No sólo los antiguos peruanos lo representaban).

http:/ / www.lomascurioso.com/foros_respuestas.php?mensaje=16877 10/3/05

BBC Mundo - NOTICIAS - "El sexo en la era prehispánica".

http://news.bbc.co.uk/hi/spanish/news/newsid_1452000/1452706.stm 22/3/05

"Cerámica erótica peruana sobrevivió a la época colonial" (Artículo de Rick Vecchio publicado en el portal "Quechua Network")

http:/ / www.quechuanetwork.org/news_template.cfm?news_id=1503\&lang=e 12/6/04

"El arte prehistórico" (en Europa) - Definiciones.

http:/ / thales.cica.es/rd/Recursos/rd98/HisArtLit/01/artepreh.htm 12/5/04

"Museo Arqueológico Larco" (Lima)

http:/ / museolarco.perucultural.org.pe/index.html 19/4/05

"The phallus in art and culture"

http://www.issir.org/prod/data/bulletins/6/phallus-art.htm 28/3/05

Moje magiczne miejsca - menhiry y dolmeni W Carnac - France. (Menhires y dólmenes de Carbac - Francia)

http:/ / www.czejarek.pl/podroze/pdr01a.php 16/4/05 
Biografía de Rafael Larco Hoyle.

http:/ / museolarco.perucultural.org.pe/biografia.shtml 19/4/05

"Museo Nacional de Arqueología, Antropología e Historia del Perú" (MNAAHP) de Pueblo Libre (Lima, Perú)

http:/ / museonacional.perucultural.org.pe/ 19/4/04

\section{Notas}

1. Notable psiquiatra y académico peruano, gran estudioso del comportamiento social y humano en el Perú y autor de libros, algunos tan polémicos como el que nos ocupa. Actualmente ejerce el decanato de la Facultad de Psicología de la Universidad Alas Peruanas, en Lima.

2. "Madre Tierra". Los incas, al igual que las culturas que los precedieron la divinizaron.

3. Si bien muchos entendidos insisten en señalar que "no había escritura en el antiguo Perú" -es decir, que tanto en el periodo preincaico como en el incario se desconocía el uso de algún sistema de comunicación ideográfica que pudiera considerarse una forma de escritura como la entendemos ahora - ,lo cierto es que las grafías de la cultura Chachapoyas (Amazonas), los pallares pintados moche (norte del Perú) o las figuras geométricas con que los incas solían decorar algunos de sus monumentos, además de ceramios y textiles (por citar sólo unos casos), parecen indicar que aún queda mucho por investigar en este apasionante rubro, no del todo desdeñable. Y eso que aquí no estamos hablando de los célebres quipus, el sistema de cuerdas de colores utilizado por los incas. 
4. No sólo es la forma "fálica" de algunas esculturas de Chavín sino también otros de sus atributos, tales como unas cabezas de serpiente que parecen deslizarse debajo de los faldellines que visten los personajes allí representados. Sin embargo, hay que recordar que en la cosmovisión andina la serpiente era sinónimo de sabiduría y de autoridad. No en vano, la gran culebra de los cielos, el Amaru, era especialmente temida pues simbolizaba el cambio, el poder inmutable, el poder de los dioses.

5. "Huaco" o "guaco", según el "Diccionario de la Lengua Española", en su vigésima edición (1984) es un "Objeto de cerámica u otra materia que se encuentra en las guacas (o huacas - N. de R.) (Nota 8) o sepulcros de los indios." Éstas, en el caso de la cultura Mochica y de otras civilizaciones preincaicas, eran "vasijas cerradas, de cuerpo globular o escultórico, base plana y con un gollete tubular en forma de asa estribo); han sido uno de los elemento primordiales para conocer no sólo el espíritu de esta cultura preincaica, sino la sociedad y el entorno natural en el que se desarrollaron. Tan comprometida con la cultura ha estado la alfarería que incluso ha sido el elemento del que actualmente nos servimos para determinar las diferentes etapas de evolución cultural Moche." (11)

6. Las manifestaciones artísticas de desviaciones sexuales no son pocas en el antiguo Perú. Cuando los españoles llegaron a "los reynos del Pirú", se toparon con muchas de estas costumbres en pueblos que habían sido conquistados por los incas, tal como revelan innumerables crónicas de los siglos XVI y XVII, que recogen referencias de tales prácticas, como ya nos cuenta Pedro Cieza de León. Por su parte, refiriéndose a la pretendida "santidad" de los viciosos, mencionada por Cieza, Fray Domingo de Santo Tomás aclara que... "verdad es que generalmente entre los serranos y yungas el demonio ha introducido éste vicio debajo de especie de santidad, y es que cada templo o adoratorio principal tiene un hombre o dos más, según es la importancia del ídolo, los cuales andan vestidos como mujeres desde el tiempo que eran niños, y hablan como tales, y en su manera, traje y todo lo demás remedan a las mujeres. Con 
éstos mozos, casi como por vía de santidad y religión, tienen los señores principales su ayuntamiento carnal y torpe los días de fiesta. Digo esto porque he castigado a dos: el uno de los indios de la sierra, que estaba parta ese efecto en un templo, que ellos llaman huaca, de la provincia de los Conchucos, de la ciudad de Guanuco; el otro era de la provincia de Chincha; ambos indios de su Majestad, a los cuáles hablándoles yo sobre esta maldad que cometían, y agravándoles la fealdad del pecado, me respondieron que ellos no tenían culpa, porque desde el tiempo de su niñez los habían puesto allí sus caciques para que los señores principales usaran con ellos éste maldito y nefando vicio y para ser sacerdotes y guardas de los templos de sus ídolos" (28). Más abajo, Domingo de Santo Tomás agrega que a pesar de que algunos indígenas decían aborrecer esta costumbre, la practicaban secretamente, y puntualiza que éstos cometían "el pecado nefando" del que habla también el cronista viajero Gutiérrez de Santa Clara (29). En cuanto a las enfermedades de transmisión sexual (ETS en el argot médico), se han encontrado ceramios de varias culturas (Vicús, Moche y Nasca) donde se aprecia a individuos de ambos sexos que sangran profusamente, o que tienen bultos en sus órganos genitales, como si estuvieran inflamados, lo cual revelaría la existencia de enfermedades de transmisión sexual como la sífilis y la gonorrea que, al parecer, fueron dos enfermedades infecciosas muy extendidas en el antiguo Perú. Estos ceramios fueron estudiados en su oportunidad por el notable arqueólogo Julio C. Tello, siendo estos tema de una de sus tesis doctorales (30).

7. Según el vocabulario quechua-aymara de "runasimi.de", tal vez uno de los diccionarios más completos sobre estas lenguas autóctonas, el significado de las palabras en estas lenguas, particularmente la que nos interesa, el quechua, es mas subjetivo que objetivo, ya que, en el caso de los significados que siguen a continuación, éstas representan variantes que responden a situaciones cotidianas complejas. Una de las particularidades de esta lengua es que hay palabras que describen situaciones o circunstancias, mientras que otros términos describen cosas 
tan simples como "casa" o "niño". En este idioma existen, pues, varias acepciones para una sola cosa, donde incluso cambia la grafía, como veremos a continuación:

misqui: (o misk'i o mishki): = dulce, sabroso; azúcar, golosina.

tincunacuy: (o tinkunakuy): = toparse dos o más personas; encontrarse, converger.

tincunacuspa: (o tinkunakuspa): = relativo a encuentro.

seriasi: $\mathrm{n} / \mathrm{d}$

topacashca: $\mathrm{n} / \mathrm{d}$

yachanacuy: de yacha - nacuy, en concreto es un lugar donde se aprende a juntarse, a ser pareja, a conocerse.

pantanacuy o pantanaco: matrimonio de prueba. De otro lado, la voz quechua servinacuy o servinakuy (para algunos sirvinacuy o sirvinakuy) es una acepción compuesta que significa "convivencia", el verdadero sentido literal de esta forma de emparejamiento. (31)

8. El término "huaca" (también "guaca") viene del quechua "uaca" (dios de la casa). Según el "Diccionario de la Lengua Española", en su vigésima edición (1984), se trata de "Sepulcro de los antiguos indios, principalmente de Bolivia y Perú, en que se encuentran a menudo objetos de valor". Pero "huaca" podía ser también un edificio, generalmente un templo, donde se han encontrado sepulcros (como sucedió con la fastuosa tumba del Señor de Sipán, descubierta en 1987 en "Huaca Rajada" (Lambayeque); esta acepción, por tanto, ha sido siempre relacionada con este tipo de estructuras-cementerio y también con la cerámica depositada en su interior ("huacos" 
o "guacos"). Por otro lado, en el Perú profundo, se suele considerar también como "huaca" a todo lugar que tenga en sí atributos relacionados con alguna leyenda ancestral, alguna divinidad o hecho acaecido en el pasado, como sucede por ejemplo con el cerro "Tamputoco", de donde se dice salieron los hermanos Ayar (32) para fundar la capital del imperio de los incas. Cerro, pero a la vez sagrado, el "Tamputoco" aún inspira respeto entre los habitantes de la región del Cusco. Por tanto, "huaca" podía ser asimismo un objeto u objetos (tal como un montón de piedras), un río, una montaña, un bosque, etc.

9. Menhir. Palabra compuesta de origen bretón $($ men $=$ piedra, hir $=$ larga) Por lo general es una piedra o monumento megalítico tallado de forma alargada e hincada en el suelo por uno de sus extremos. Algunos tienen en la parte superior otra piedra o se les ha tallado una especie de "prepucio" que señala al cielo. Según algunas tradiciones nórdicas, representan la unión entre la Tierra con los dioses; para otros, eran el canal por el que fluían las fuerzas telúricas de la Naturaleza.

10. Pampayruna. Voz compuesta del quechua que viene de pampa (plaza o espacio abierto o lugar público), y runa (persona, ya sea hombre o mujer).

11. Sodomía. En realidad ésta es otra definición de homosexualidad. Algunos autores señalan que entre los mochicas y los chimú se realizaban tales prácticas, pero puntualizan sobre la finalidad ritual de las mismas. Este término viene de Sodoma, célebre ciudad palestina donde sus habitantes vivían entregados a tales vicios que, según la Biblia, fueron castigados por Dios. Sobre este vicio en los Andes peruanos, Garcilaso.

12. Hasta tal punto que una trasgresión era penada con la muerte, como ya hemos visto en el capítulo 6. Pampayrunas: prostitutas del incario. Lo curioso es que el cronista Antonio de Herrera y Tordesillas, en su obra "Historia general de los hechos 
de los castellanos en las islas, y Tierra-Firme de el mar Océano" de 1601-15, hace una relación de las penas con que la justicia incaica castigaba los delitos, pero no dice nada de las condenas contra las prostitutas. Sin embargo, sí habla del castigo al lenocinio o alcahueteo (sakeri en la lengua aymara). -El "Diccionario de la Lengua Española", en su vigésima edición (1984), define al alcahuete como una "persona que solicita o sonsaca a una mujer para usos lascivos con un hombre, o encubre, concierta o permite en su casa esta ilícita comunicación" - , del que el autor señala que... "Al alcahuete le daban tormento públicamente, habiendo junta de gente, y si perseveraba en el vicio, le mataban" (Herrera 1945, V, IV, III).

\section{Fuentes}

(Nota: A la derecha de los hipervínculos se ha insertado la fecha de última apertura de la página Web citada)

1. Editorial Universo. Primera Edición. Lima, 1992.

2. "Museo Brüning", Lambayeque, Perú.

http:/ / www.regionlambayeque.gob.pe/guia/museo.htm 22/3/05

\section{Cultura Vicús.}

http:/ / reynaldomoya.tripod.com.pe/vvcs.htm 22/3/05

\section{Cultura Vicús (Idem 3.)}

\section{Cultura Paracas.}

http://www.morrion.com/peru/preinca/Cult_Preincaicas/FORMATIVO/PARA CAS/paracas.html 24/3/05 
6. Julio C. Tello: el padre de la arqueología peruana.

http://www.antropologia.com.ar/peru/tello.htm 0710/04

7. Cultura Chavín.

http://www.morrion.com/peru/preinca/Cult_Preincaicas/FORMATIVO/CHAVI N/chavin.html 15/4/05

8. Cultura Tiahuanaco o Tiwanaku.

http://victorian.fortunecity.com/

klimt/83/arteperu/hframe3.html 12/5/04

9. The Kinsey Institute.

http://www.indiana.edu/ kinsey/ 19/4/05

10. Cultura Nasca.

http:/ / nasca.museumonline.at/start-sp.htm 12/5/04

11. Cultura Mochica. 22/3/05

http://www.morrion.com/peru/preinca/Cult_Preincaicas/D__REGIONALES/ MOCHE/moche.html 24/3/05

12. Cultura Chimú.

http://www.morrion.com/peru/preinca/Cult_Preincaicas/E_REGIONALES_T_ /CHIMU/chimu.html 24/3/05

13. "La Sexualidad en el antiguo Perú". Revista "Actualidad Psicológica" de la Facultad de Psicología de la UPCH.

http://www.angelfire.com/pe/actualidadpsi/sxperu.html 06/4/04 
14. Universidad Peruana Cayetano Heredia (Lima).

http:/ / www.upch.edu.pe 16/4/05

15. "Mito Tradición e Historia del Perú" Ediciones Retablo de papel. Lima, 1973. (13)

16. "El Imperio de los Incas".

http:/ / www.sir.edu.pe/Feria/Bernini/PaginaWeb/tahuantinsuyo.htm 12/12/04

17. "Huaca de la Luna" (Valle de Moche, Trujillo).

http://www.huacadelaluna.org.pe/ 06/4/05

18. "El matrimonio en tiempo de los Incas".

http://www.camdipsalta.gov.ar/ANTROPO/casamien.htm 12/5/04

19. Diario "El Peruano":"El sirvinacuy, resistencia cultural".

http://www.editoraperu.com.pe/edc/02/04/22/cul3.htm 12/5/04

20. "Los Incas. Economía, sociedad y Estado en la era del Tahuantinsuyo". Amaru Editores. Primera Edición, pp. 295 - 296. Lima, 1987.

21. "¿Prostitución en tiempo de los incas?".

http:// www.camdipsalta.gov.ar/ANTROPO/prost.htm 24/3/05

22. PEISA Editores, pp. 302 - 304. Lima. 1971.

23. Revista Caretas. Edición 1677. 5 de julio de 2001. Sección Cultural.

http://www.caretas.com.pe/2001/1677/secciones/cultural.phtml 12/5/04

24. Introducción al "Mundo Mochica". "Museo Arqueológico Larco" (Lima). 
http:/ / museolarco.perucultural.org.pe/espanol/represen.htm 28/3/05

25. "Un extraño Templo a la Fertilidad".

http://www.enjoyperu.com/magazine/otros-artic/ chucuito-Un-extrano-templo-ala-fertilidad/index 2.htm 12/5/04

26. Op. cit, pp. 197. Lima, 1987 (20).

27. "Primera Parte: Del Señorío de los Incas". Madrid, 1553.

28. "Lexicón o Vocabulario de la Lengua General del Perú". (1560) Edición facsimilar. Lima, 1951.

29. "Quinquenario o Historia de las guerras civiles en el Perú y de otros sucesos de las Indias". (1600) Madrid, 1963.

30. "La antigüedad de la sífilis en el Perú" - Una tesis de Julio C. Tello.

http:// sisbib.unmsm.edu.pe/bibvirtual/tesis/Antiguos/Tello_J_1909/indice.htm 19/4/05

31. Vocabulario runasimi ("el habla de la gente" o quechua).

http:/ / www.runasimi.de/runaespa.htm 07/10/04

32. "La leyenda de los hermanos Ayar".

http:// ciudadinca.perucultural.org.pe/fundacion2.htm 12/12/04

33. "La prostitución en el Perú: Un producto de la conquista española". (Un enfoque diferente del historiador peruano Juan José Vega).

http:// webserver.rcp.net.pe/cemhal/capitulo3.html 06/4/05 
34. Los falos de Monsaraz (Portugal).

http://www.revistaiberica.com/Suscripcion/Apoyos_gr/los_falos_de_monsaraz.ht m 24/3/05

35. "Cerámica erótica peruana sobrevivió a la época colonial".

http://www.quechuanetwork.org/news_template.cfm?news_id=1503\&lang=e 20/4/05

36. "Patronato Huacas del Valle de Moche"

http:// www.huacadelaluna.org.pe/Cronologia.asp 19/4/05

37. Espacio temporal de la Cultura peruana.

http://www.peru.com/preincas/cuadro.htm 20/4/05

38. "Museo en Perú es ejemplo de que los primeros pobladores de nuestro continente sí sabían de erotismo".

http://www.teletica.com/archivo/7dias/2003/01/museo.htm 20/4/05

39. "El verdadero rostro de los mochicas". Revista "Muy Interesante". Editorial Cinco, año 17, \# 197, pp. 17. Bogotá, Colombia.

40. "Proyecto Arqueológico Ai-Apaec". Universidad de Trujillo (Perú) http://www.unitru.edu.pe/arq/hluna.html 20/4/05

41. Basado en la "Tabla cornológica" del libro "Perú Preincaico". Editorial Librería Studium, novena edición, pp. 331 - 348. Lima, 1988. 


\section{Origen de las imágenes}

(Nota: A la derecha de los hipervínculos se ha insertado la fecha de última apertura de la página Web citada)

1b. Mapa de las culturas peruanas precolombinas.

http://victorian.fortunecity.com/klimt/83/arteperu/hframe2.html 19/4/05

2. La figura de Frías.

http:/ / reynaldomoya.tripod.com.pe/vvcs.htm 29/3/05

3. Un manto de Paracas similar a este llamó la atención al doctor Cáceres. http://www.picturesofrecord.com/ paracas\%20textiles020.htm 15/4/05

4a. Estatuas de piedra del "Museo Regional de Huaraz" (Ancash, Perú). http:/ / barrioperu.terra.com.pe/drita/huaraz.html 15/4/05

4b. ¿Una vinculación de "deidades" antropomorfos con atributos sexuales masculinos...

http://www.morrion.com/peru/preinca/Cult_Preincaicas/FORMATIVO/CHAVI N/chavin.html 19/4/05

5. Ceramio nasca con dos rostros, presumiblemente un bisexual.

http://www.morrion.com/peru/preinca/Cult_Preincaicas/D__REGIONALES/ NASCA/Ceramica_N/ceramica_n.html 15/4/05

6a. Secuencia de huacos-retratos del libro "Arqueología Peruana". Op. Cit. pp. 295 (22). 
6b. En esta segunda secuencia, procedente de la misma obra de Kauffmann Doig, podemos apreciar tres figuras míticas... Op. Cit. Op. Cit. pp. 296 (22).

6c. "'"Rostro de madre feliz..." Op. Cit. pp. 297 (22) .

6d. Personaje con uta. Ilustración del portal de la Sociedad Peruana de Dermatología SPD.

http:/ / www.concytec.gob.pe/spd/emblema.htm 16/5/04

6e. "Huaco antropomorfo que representa un enfermo con tumores y mutilaciones". http:// sisbib.unmsm.edu.pe/bibvirtual/tesis/Antiguos/Tello_J_1909/indice.htm $15 / 4 / 05$

7a. Ceramio de Virú o Gallinazo pintado en color neutro.

http:/ / arqueologia.deperu.com/viru.html 20/4/05

7b. Vasija de "estribo", estilo "Salinar".

http:/ / victorian.fortunecity.com/klimt/83/arteperu/hframe3.html 20/4/05

7c. Curiosa botella con Forma Fálica de Cultura Vicús.

http:/ / exchanges.state.gov/culprop/1peru/00000075.htm 20/4/05

8a. Mapa general del Perú con la ubicación del reino moche.

http://www.morrion.com/peru/preinca/Cult_Preincaicas/D__REGIONALES/ MOCHE/moche.html 19/4/04

8b. Mapa detallado con los principales asentamientos de la cultura Moche.

http://www.morrion.com/peru/preinca/Cult_Preincaicas/D__REGIONALES/ MOCHE/moche.html 19/4/04 
8c. El "Degollador" de Moche en un mural de la "Huaca de la Luna" (Trujillo, Perú) Foto del "Patronato Huacas del valle de Moche".

http:/ / www.huacadelaluna.org.pe/Galeria.asp 16/4/05

9a. "Vasija cubicular con aplicaciones antropomorfas. Pareja durante el acto sexual". Pieza original del "Museo Larco". Exposición Temporal "Ofrendas funerarias y arte erótico en el Perú antiguo". "Museo Nacional de Colombia", Bogotá, diciembre 2000 a febrero 2001.

http:/ / www.museonacional.gov.co/peru.html 16/4/05

9b. Idolillo que representa a un hombre con prominente miembro viril. Cultura Mochica. 1 - 800 D.C. Época: Auge.

http:/ / museolarco.perucultural.org.pe/ep_er.shtml 16/4/05

9c. "Botella escultórica realista representando a mujer amamantando a infante" Cultura Mochica. 1 - 800 D.C. Época: Auge.

http:/ / museolarco.perucultural.org.pe/ep_er.shtml 16/4/05

9d. "Botella escultórica realista representando escena sexual entre hombre y mujer". Cultura Mochica. 1 - 800 D.C. Época Auge.

http:/ / museolarco.perucultural.org.pe/ep_er.shtml 16/4/05

9e. "Botella escultórica realista representando escena sexual entre hombre y mujer". Cultura Mochica. 1 - 800 D.C. Época Auge.

http:/ / museolarco.perucultural.org.pe/ep_er.shtml 16/4/05

9f. "Botella escultórica humorística representando genitales masculinos". Cultura Mochica. 1 - 800 D.C. Época Auge.

http:/ / museolarco.perucultural.org.pe/ep_er.shtml 16/4/05 
10. Menhires del conjunto megalítico de Evora (Portugal).

http://www.bikeiberia.com/rides/rrone.html 20/4/05

11a. Mapa de la región del lago Titicaca, donde se puede apreciar la ubicación de la ciudad de Chuchito, sede de esta extraña edificación.

http:/ / www.ladatco.com/TITI-map.htm 16/4/05

11b. Vista general del famoso "Templo de la Fertilidad" o "Inca Ullu", con la iglesia colonial de Chucuito al fondo.

http:// www.earthtravel.net/travels/southamerica/Bolivia/la\%20Paz_day6.htm $17 / 4 / 04$

11c. Un detalle de esta extraña edificación.

http:/ / www.earthtravel.net/travels/ southamerica/Bolivia/Bolivia.htm 17/4/04

12. La extraña roca "invertida" de Q'enqo, cerca al Cusco, aún genera controversia. http:/ / www.giro2000.com.br/py/giro423e.htm 17/4/05

13. "La primera historia de las reinas coyas", es el título de esta ilustración del cronista mestizo Guamal Poma de Ayala, fechada en 1615.

http://www.camdipsalta.gov.ar/ANTROPO/casamien.htm 10/10/03

14. "Virgen del Sol o aklla colgada de los cabellos en un araway junto a su amante, por transgredir las normas del imperio Inka."

http://www.camdipsalta.gov.ar/ANTROPO/prost.htm 24/3/05

15. El arqueólogo Federico Kauffmann Doig mostrando las ilustraciones de uno de sus libros. Foto del Museo Larco publicada por la revista "Rumbos del Perú" \# 28 . http:/ / www.rumbosdelperu.com/ed_ant_es/edic28/der_rumbhist.htm 18/4/05 
16. Ilustraciones del libro de Kauffmann Doig. Op. Cit. pp. 302 - 303 (22).

\section{Recortes}

15.1. Museo en Perú es ejemplo de que los primeros pobladores de nuestro continente sí sabían de erotismo.

Publicado en el portal "7 Días". Lunes 20 de enero de 2002 (38).

Escribe: Patricia Jiménez

"Nuestra sociedad, aunque conservadora, considera que sabe mucho sobre sexo, sin embargo, no descubrimos el agua tibia. Miles de años antes de Cristo, nuestros aborígenes eran expertos en esta materia.

Si usted visita Perú, tiene que ir a las instalaciones del Museo Larco Herrera, ubicado en el corazón de Lima. No es un museo más, sus paredes guardan una de las colecciones más importantes del mundo.

Se trata de una muestra de arte erótico creado por manos americanas que existieron miles de años antes de cualquier contacto europeo. Son 120 huacos o piezas aborígenes de la cultura Mochica.

Ahí nos dejaron un legado en donde el sexo no puede ser más explícito. En el recorrido, las vitrinas lo muestran todo, penes, vaginas, coitos, masturbaciones, sexo anal y oral. Para Ulla Holmquist, arqueóloga, todas las piezas tienen un sentido "en el conjunto de las representaciones de las culturas precolombinas, no es un tema aislado, para entenderse tiene que ser vinculado con otros temas de la cosmovisión del poblador precolombino". 
Es así como la sexualidad era parte esencial de sus vidas, pero no tanto en un sentido lujurioso, sino más bien como relación estrecha entre la divinidad y la fecundidad. "Ellos representaban no sólo lo que hacían, sino también aquello que para ellos era realmente importante", agregó la arqueóloga.

Según el sociólogo Francisco Escobar, estos pobladores utilizan la experiencia sexual para representar la región más importante de la vida espiritual humana: la amorosa.

Las piezas son sencillas, bien elaboradas y se hicieron para las verlas, sin necesidad de explicaciones.

Todas tienen orden lógico. Se muestra la intimidad de las parejas, con y hasta sin sabanas.

En algunos casos, la mujer hace el amor encima del hombre y en otras es él, quien controla la relación.

El coito, se ve muy real en cada pieza. Y al final, la mujer muestra su vagina en posición de parto, uno de los momentos más sublimes de la reproducción.

Para algunos expertos, esta muestra no deja ninguna duda de que el mito del sexo lo imponen las nuevas generaciones, pues las anteriores lo veían totalmente natural, sin morbo, prejuicios y la palabra pecado en esta materia ni siquiera existe.

La exposición también incluye el sexo oral, la masturbación y el sexo anal.

Cualquiera diría que estas son prácticas nuevas, de la inquietud moderna de la sexualidad, pero no, no descubrimos el agua tibia en esta materia. "La sexualidad no 
es algo nuevo, siempre ha tenido su manera de representarse y vivirse", detalló la sexóloga Carmen Aviar.

La colección muestra lo que han denominado como vasos moralizadores, cuyo objetivo es demostrar cómo los excesos sexuales afectan el dominio del espíritu, anulando la voluntad.

También, los vasos humorísticos, que obligan a quien bebe a hacerlo por un conducto en forma de pene.

Los muertos también son parte de estos huacos eróticos. Hay representaciones de una unión sexual contra natural.

Y es que no creían que todo acabara con la muerte del cuerpo, más bien que se iniciaba una nueva vida, "porque hay momentos en que la sociedad debe permitir la inversión del orden. Es necesario invertir el orden en que se dan las cosas, para que se vuelva a establecer ese orden", agregó Holmquist.

Estas piezas se usaban mucho en rituales como sacrificios o funerales y algunos se enterraban con los muertos para que los acompañaran en otra vida.

Pero esta colección no sólo se da en la antigua cultura andina, otros países también dejaron un legado erótico. Ese es el caso de La India.

Y no nos vayamos tan lejos, nuestros aborígenes de la Gran Nicoya y el área central del Atlántico confeccionaron estas piezas. Se encuentran en el Museo de Jade. Según investigaciones, quienes las hacían eran las mujeres y su inspiración la música. Zulia Soto, directora de este museo, indicó que han comprobado que casi todas las representaciones haciendo el amor, fueron usadas como instrumentos musicales. 
Según los expertos, todas estas piezas dejan el morbo a un lado, para abrir nuestros ojos a una sexualidad plena que nuestros antepasados disfrutaron como mágica y espiritual." 